\title{
Comparison of Cretaceous granitoids of the Chaun tectonic zone to those of the Taigonos Peninsula, NE Asia: rock chemistry, composition of rock forming minerals, and conditions of formation
}

\author{
P. L. Tikhomirov ${ }^{1}$, M. V. Luchitskaya ${ }^{2}$, and I. R. Kravchenko-Berezhnoy ${ }^{2}$ \\ ${ }^{1}$ Moscow State University, Moscow, Russia \\ ${ }^{2}$ Geological Institute, Russian Academy of Sciences, Moscow, Russia
}

\begin{abstract}
The Cretaceous granitoid complexes of the Eastern Taigonos and the Prybrezhny Taigonos belts (southern part of the Taigonos Peninsula), Tanyurer pluton of the Okhotsk-Chukotka volcanic belt, and the Peekiney, Moltykan, and Telekay plutons of the Chaun tectonic zone are discussed in relation to their structural position, petrography, rock and mineral chemistry and physicochemical conditions of melt crystallization. These granitoid plutons were generated through melting of a compositionally heterogeneous crustal source, with direct contribution from mafic melts produced in the mantle wedge above active or extinct Benioff zones. Variations of the trace-element composition of granitoids are controlled to a greater extent by local compositional peculiarities of the source regions than by the geodynamic regime as such. The final crystallization of these plutons occurred at comparatively shallow depths, between 1-2 and 6-7 km, in a temperature interval of $700-770^{\circ} \mathrm{C}$. The depth of emplacement of the bodies decreases with increasing distance from the areas with oceanic and transitional type crust, as does the degree of incompatible element enrichment of the mantle and crustal sources of melts. Variations in $\mathrm{fo}_{2}$ values at the late stages of crystallization of the plutons reach 3-4 orders of magnitude, exceeding the limits of the quartz-fayalite-magnetite (QFM) and nickel-nickel oxide (NNO) buffer equilibria, which likely results from local variations of the source composition.
\end{abstract}

\section{Introduction}

The relationship between the geodynamic factors and the compositional variations of granites has been a focus of scientific attention since the beginning of the 20th century

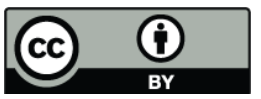

Correspondence to: M. V. Luchitskaya (luchitskaya@ginras.ru)
(Read, 1957, and references therein). At present, there are a number of classifications of granitic rocks based on their tectonic setting, bulk rock chemistry and modal mineral composition, as well as on less traditional parameters like zircon morphology, composition of mafic minerals, related mineralization, etc. Most types of classifications, more or less, correspond to each other (Barbarin, 1990). However, the geodynamic interpretation of granites may be ambiguous, because of contributions from multiple magma sources (e.g., Czamanske et al., 1981; Harmon et al., 1984; Pitcher, 1987). In this respect, one way to enhance our knowledge of the factors that control the compositional characterictics of granites, is the detailed comprehensive study of granitic plutons in new, yet poorly studied magmatic provinces.

Northeastern Asia has been accessible for systematic geologic study roughly since the beginning of 20th century (Rokhlin, 1938). During the 1950s to 1990s, this area was intensely explored by local organizations of the Soviet Ministry of Geology but those inverstigations were mainly focused on mapping and prospecting goals, thus the high quality analytical data for geologic complexes of Russian Northeast are still somewhat scanty. Within an area of over 2 million $\mathrm{km}^{2}$, occupied by complexes accreted to NE margin of the Siberian craton during Paleozoic and Mesozoic time, the Late Jurassic-Cretaceous granitic plutons make up the majority of exposed plutonic bodies and strongly affect the regional metallogeny. This paper represents the results of the initial stage of our research on the granitic rocks of NE Asia. Here we consider the geological, geochemical and petrological characteristics of six granitic plutons which represent two different types of geodynamic setting: (1) subductionrelated plutons: Eastern Taigonos and Prybrezhny Taigonos belts (southern part of the Taigonos Peninsula), and Tanyurer pluton of the Okhotsk-Chukotka volcanic belt (OCVB); (2) Peekiney, Moltykan, and Telekay post-orogenic plutons from the Chaun tectonic zone. 


\section{Geological framework}

In NE Asia four large tectonic elements with different structural styles and history of development are distinguished: Siberian platform, Verkhoyansk-Chukotka and Koryak-Kamchatka fold belts, and Okhotsk-Chukotka volcanic belt (OCVB) (Fig. 1). Verkhoyansk-Chukotka and Koryak-Kamchatka fold belts have different structural patterns from each other (Sokolov, 2003). They are separated and overlapped by the Okhotsk-Chukotka volcanic belt, which marks a Late Cretaceous Andean type continental margin. The Verkhoyansk-Chukotka Mesozoic structures (Mesozoides) mainly trend northwest and were formed as a result of collision (Tilman, 1980; Zonenshain et al., 1990; Pusharovsky et al., 1992; Parfenov et al., 1993; Sokolov, 2003). Their structure is heterogeneous and composed of structural elements including complexes of both passive and active plate margins.

The Verkhoyansk fold system is located on the eastern margin of the Siberian platform and is composed of thick Paleozoic to Early Mesozoic carbonate and terrigenous deposits which were accumulated in a passive continental margin environment. Further to the east the structures within the "Kolyma Loop" (Zonenshain et al., 1990) (KolymaOmolon superterrane) include allochthonous terranes, composed of continental formations, deep water terrigenous deposits, island arc, ophiolite and oceanic complexes. In the north and west they are separated from the Anyui-Chukotka branch of Mesozoides which contain Precambrian basement and Paleozoic-Mesozoic cover near the South-Anyui suture zone. The latter is a remnant of the Anyui-Angayucham (South-Anyui) oceanic basin which separated the Siberian continent from the Chukotka (Arctic Alaska-Chukotka) microcontinent until the end of Neocomian time (Natal'in, 1984; Parfenov et al., 1993; Sokolov et al., 2002). Along the southern margin of the Chukotka block island arc structures were active, whereas the northern edge was a passive continental margin. Koryak-Kamchatka fold area is located to the east from the OCVB and has northeastern and eastern trends. It is a typical example of an accretionary continental margin, formed as a result of successive terranes accreting to the continent from Middle Jurassic until Middle Miocene time (Sokolov, 1992, 2003). Terranes have island arc, ophiolite, marginal sea, turbidite, oceanic crust and accretionary prism origins (Essays, 1982; Stavsky et al., 1988; Sokolov, 1992; Parfenov et al., 1993).

The plutons studied are located within three different tectonic zones: (1) the Taigonos Peninsula segment of the West Koryak fold system which occupies the junction area between the Verkhoyansk-Chukotka and the KoryakKamchatka fold belts (Fig. 1), (2) the Chaun zone of the Verkhoyansk-Chukotka fold belt, and (3) the northern part of the OCVB.

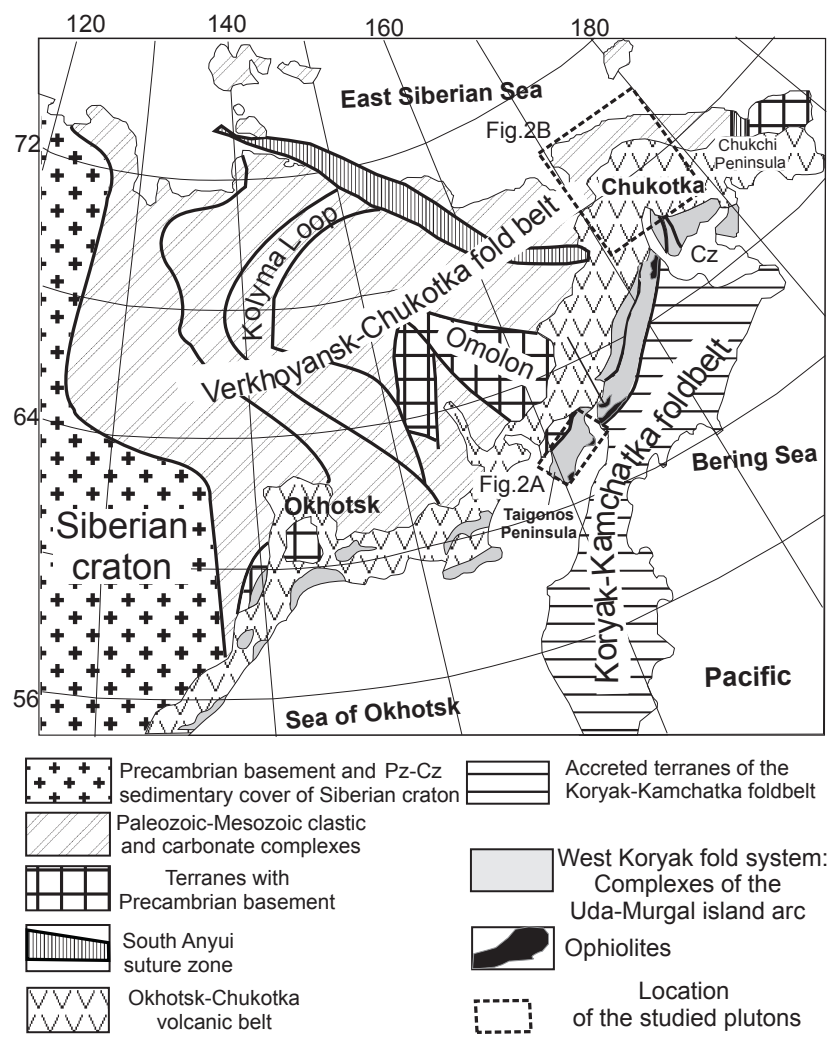

Fig. 1. Tectonic map of Northeastern Asia (after Sokolov et al., this volume).

\subsection{West Koryak tectonic zone}

The structures of the West Koryak tectonic zone have linear orientations discordant with the structural patterns of Verchoyansk-Chukotka and Koryak-Kamchatka fold belts. This tectonic zone consists of wide-spread Late Paleozoic to Early Cretaceous island arc complexes including accreted ophiolites (Markov, 1975; Nekrasov, 1976; Zaborovskaya, 1978; Essays, 1982; Pusharovsky et al., 1992; Sokolov, 1992; Parfenov et al., 1993).

\subsection{Taigonos segment, West Koryak zone}

The Central Taigonos and Beregovoy exotic terranes lie within the Taigonos segment of the Western Koryak tectonic zone Sokolov et al., 2001) (Fig. 2a), separated by the South Taigonos thrust. To the north, the Central Taigonos terrane borders with the Avekov terrane along the Pylgin suture zone. Avekov terrane is composed of Precambrian and Lower Paleozoic metamorphic rocks, overlapped by a weakly deformed cover of Upper Paleozoic rocks (Nekrasov, 1976; Zaborovskaya, 1978; Zhulanova, 1990). It is considered to be part of the Omolon microcontinent, separated as a result of Late Paleozoic rifting (Tilman, 1980). The Central Taigonos terrane is composed of sedimentary-volcanic complexes, 


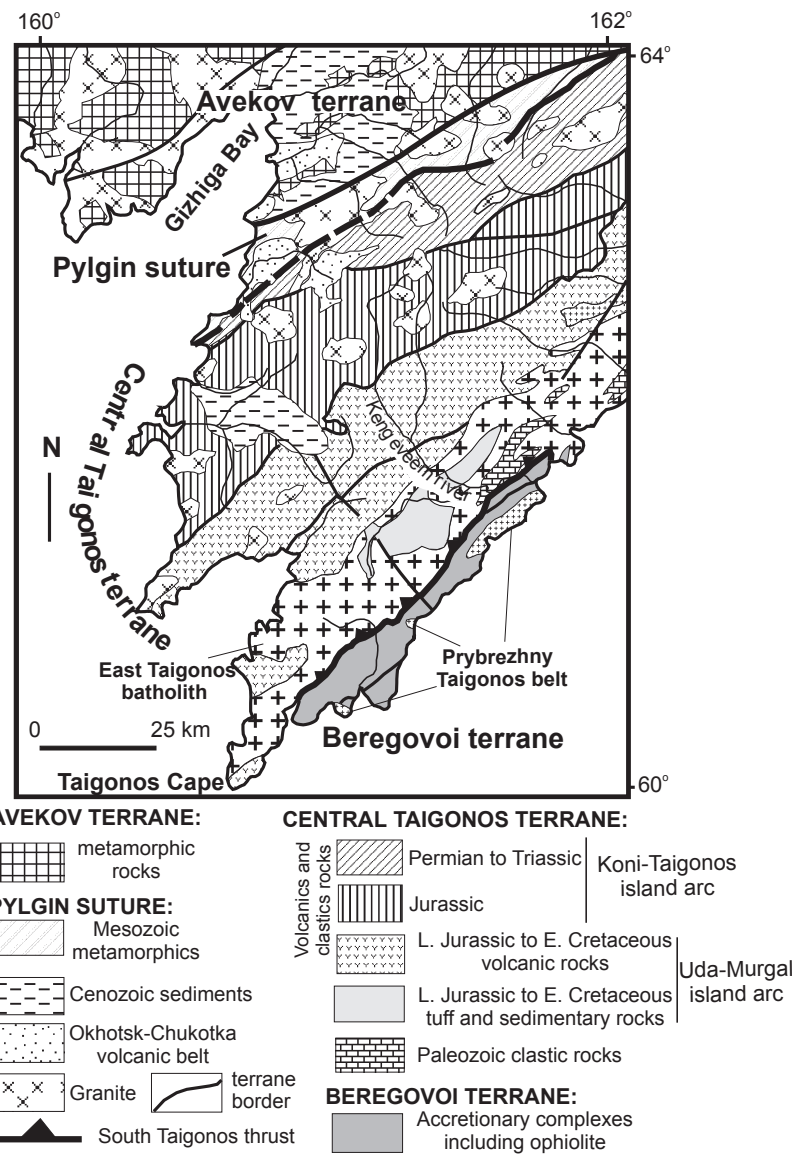

(a)
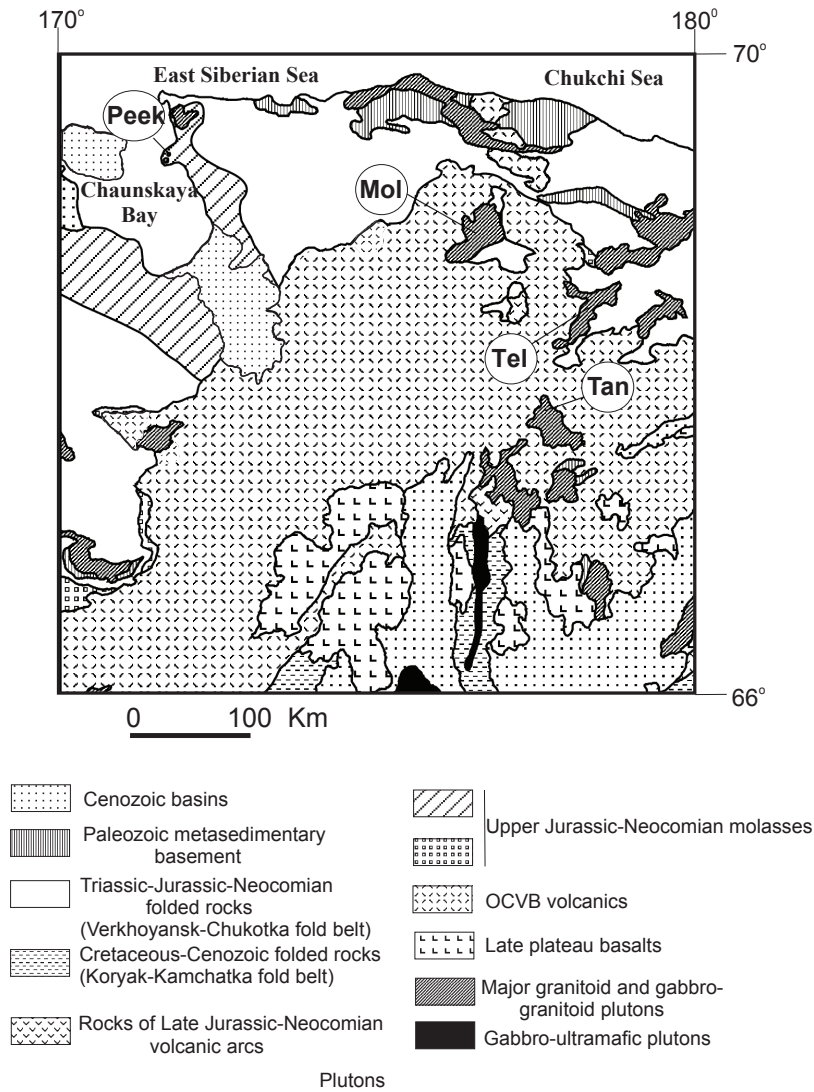

(b)

Tan Tanyurer Peek Peekiney Mol Moltykan Tel Telekay

Fig. 2. Sketch maps showing geological setup of Taigonos Peninsula (a) and Central Chukotka (b). Sketch map (a) is based on Sokolov et al. (2001); sketch map (b) is constructed on the basis of the Geological Map of the USSR, 1:2 500000 scale (1983) with minor changes. Plutons: Tan - Tanyurer, Peek - Peekiney, Tel - Telekay, and Mol - Moltykan.

generated in the framework of the Koni-Taigonos (PermianEarly Mesozoic) and the Uda-Murgal (Late Jurassic-Early Cretaceous) island arcs (Sokolov, 1992). In the south, the Central Taigonos terrane is intruded by Albian granitoids of the Eastern Taigonos batholith. Roof pendants of the pluton and thrust sheets occurring along the South Taigonos thrust (Fig. 2a) in places contain terrigenous deposits of Ordovician and Carboniferous age, fragments of ophiolite assemblages, and tuffaceous-terrigenous deposits of Upper Jurassic-Valanginian age (Nekrasov, 1976; Chekhov and Palandzhyan, 1995). The Beregovoy terrane displays an imbricate thrust structure, mostly south vergent, and is interpreted as the accretionary prism of the Uda-Murgal arc (Sokolov et al., 2001), stitched by granitoids of the Prybrezhny Taigonos belt. The Central Taigonos and Beregovoi Terranes are thought to comprise the arc-forearc-accretionary wedge system of the Uda-Murgal arc. The Eastern and Prybrezhny Taigonos granitoids have supra-subduction origins and are related to the final stages of the Uda-Murgal arc development.

\subsection{Chaun fold zone}

The Chaun fold zone (Fig. 2b) is dominated by Early Mesozoic rock assemblages of the passive margin of the Chukotka microcontinent (Parfenov et al., 1993). The northern part of this zone comprises several uplifts with outcrops of Devonian to Carboniferous sedimentary rocks, separated by synclinoria composed of terrigenous clastic sequences of PermianTriassic age. Paleozoic and Early Mesozoic strata are gently folded, with dominating NW striking fold axes. The western part of the Chaun zone is overlain by slightly deformed Late Jurassic to Neocomian clastic sediments of the Rauchua basin, probably of syn-collisional nature (Miller et al., 2004). To the south, complexes of the Chaun zone are concealed by thick (up to $3-4 \mathrm{~km}$ ) undeformed sequences of the OCVB. Granitic plutons of the Chaun zone form several chains with NW and NE strikes. They intrude both folded Triassic and weakly deformed Jurassic-Early Cretaceous sediments, indicative of their emplacement during the post-orogenic stage, well after the closure of the Anyui-Angayucham oceanic 
basin. Therefore, the direct relationship of Chaun granites with an active subduction zone looks unlikely. Their formation could be related to slab delamination at the extinct subduction zone of the former Anyui-Angayucham ocean, or to processes at the active margin of the ancestral Pacific (like back-arc extension or strike-slip stress).

\subsection{Okhotsk-Chukotka volcanic belt}

The Okhotsk-Chukotka volcanic belt (Fig. 1) is the huge subduction-related continental volcanic province, roughly $3000 \mathrm{~km}$ long and 100 to $300 \mathrm{~km}$ wide. It was formed during Albian through Campanian time (ca. 106 Ma to $75 \mathrm{Ma}$ ) (Tikhomirov et al., 2006a, and references therein), and is thought to be related with the subduction of Kula and Isanagi oceanic plates (Ueda and Miyashita, 2005) under the collage of terranes finally accreted to the Siberian craton before Albian time (Parfenov et al., 1993; Nokleberg et al., 2001). Conventionally, the OCVB is subdivided into several segments with various volume proportions of intermediate and felsic rocks (Belyi, 1977). The volcanic strata are up to $6 \mathrm{~km}$ thick and almost undeformed, excluding deformation due to caldera formation. The volcanic sequences host a number of coeval granitic and gabbro-granitic plutons.

\section{General characteristics of the studied plutons}

\subsection{Granitoids of the Taigonos peninsula}

\subsubsection{Eastern Taigonos batholith}

This batholith has a distinct linear northeastern orientation. It is $200 \mathrm{~km}$ long and $25 \mathrm{~km}$ wide. The most deeply eroded northeastern part of the batholith consists of a series of sheets of gneissose granitoids, separated by thrust sheets composed of amphibolite facies metamorphic rocks. In the southwest, where the erosional incision is less deep, the batholith has a shape of a phacolith (a lense-like pluton confined to the crest of an antiform). The batholith comprises a wide spectrum of rocks from gabbro-diorite through plagiogranite, dominated by granodiorite and tonalite (Nekrasov, 1976; Luchitskaya, 2001). Structural relationships between the petrographic varieties are ambiguous: both sharp phase boundaries and gradual transitions are recorded. The granodiorites are massive light gray medium-grained rocks, composed of $\mathrm{An}_{40-25}$ plagioclase (55-75\%), quartz (12-15\%), K-feldspar (5-15\%), amphibole (7-8\%), and biotite (4-6\%); among accessory phases, apatite, zircon and Ti-magnetite are common. The tonalites differ from the granodiorites in having low, no higher than $1 \%$, K-Na-feldspar abundances and in containing magmatic sphene. Marginal parts of the batholith consist of more mafic rocks: gabbro-diorite, diorite, and quartz diorite. Amphibole-biotite granite and leucogranite are encountered in subordinate amounts.
$\mathrm{U}-\mathrm{Pb}$ zircon dates suggest that granitoids of the Eastern Taigonos batholith were emplaced at $104.6 \pm 1.1$ to 97.0 $1.1 \mathrm{Ma}$ (Hourigan, 2003; Luchitskaya et al., 2003) (Table 1). Bondarenko et al. (1999) report ${ }^{40} \mathrm{Ar} /{ }^{39} \mathrm{Ar}$ ages of the biotite from Eastern Taigonos granites ranging from $103.3 \pm 0.3$ to $102.1 \pm 0.4 \mathrm{Ma}$ (Table 1 ). Thus, this intrusive body was emplaced during the Albian time, and suffered relatively rapid post-intrusive cooling.

\subsubsection{Prybrezhny Taigonos}

Most of the plutons of the southwestern part of Prybrezhny Taigonos belt are small (a few kilometers across) and almost equant in shape. They intrude non-metamorphosed Middle Jurassic-Berriasian volcanic and sedimentary rocks. The latter are comprised of lithic and volcaniclastic turbidite, with fragments of ultramafic rocks, gabbro, basalts and cherts; these units are interpreted as olistostromes that have a sedimentary origin. Geochemical fingerprints of the volcanic rocks correspond to those of ensimatic island arcs including boninite series (see paper Sokolov et al., this volume). According to data by Nekrasov (1976) in the northeastern part of Prybrezhny Taigonos belt the inrusions of diorites and gabbro-diorites are concordant to amphibolite-grade metasedimentary and metavolcanic host rocks.

The plutons include rocks of a wide compositional range, from gabbro through diorites and quartz diorites to tonalites and granodiorites. Transitions between the petrographic varieties are gradual. The gabbro is massive coarse-grained rock composed of $\mathrm{An}_{55-50}$ plagioclase, amphibole, orthorhombic pyroxene, and clinopyroxene in various proportions. The tonalite is composed of $\mathrm{An}_{45-25}$ plagioclase (65-80\%), quartz (15-20\%), amphibole (1-7\%), biotite (2-8\%), and K-Na-feldspar (ca. 1\%); of the accessory minerals, apatite, sphene, Ti-magnetite, and ilmenite are present.

Two zircon U-Pb dates of Prybrezhny Taigonos granitic rocks are available, $106.5 \pm 0.9 \mathrm{Ma}$ and $105.5 \pm 0.9 \mathrm{Ma}$ (Hourigan, 2003; Luchitskaya et al., 2003) (Table 1), as well as four ${ }^{40} \mathrm{Ar} /{ }^{39} \mathrm{Ar}$ determinations on biotite and amphibole which range between $103.5 \pm 1.9$ and $100.9 \pm 0.6 \mathrm{Ma}$ (Bondarenko et al., 1999). Within the analytical errors, this is close to the age of the Eastern Taigonos batholith. The difference between $\mathrm{U}-\mathrm{Pb}$ and ${ }^{40} \mathrm{Ar} /{ }^{\beta 9} \mathrm{Ar}$ ages of Prybrezhny Taigonos plutons could result from a realtively slow postintrusive cooling.

\subsection{Granitoids of the Chaun fold zone}

\subsubsection{Peekiney pluton}

This pluton is the central body of the Pevek group, a NE trending chain of 3 nearly equant plutons. Granitic rocks are exposed on the eastern coast of the Chaunskaya Bay, in the eastern margin of the the Rauchua basin. In plan view, the granitic body is $2.5 \mathrm{~km}$ by $3 \mathrm{~km}$ in size. Its country 
Table 1. Selected isotopic age data for granitic plutons studied.

\begin{tabular}{|c|c|c|c|c|c|}
\hline Tectonic setting & Pluton & Mineral & Age, Ma & Method & Reference \\
\hline \multirow[t]{5}{*}{$\begin{array}{l}\text { West Koryak } \\
\text { fold area }\end{array}$} & $\begin{array}{l}\text { Eastern- } \\
\text { Taigonos }\end{array}$ & biotite & $\begin{array}{l}102.1 \pm 0.4 / 103.1 \pm 0.5 \\
102.3 \pm 0.3 / 103.3 \pm 0.3\end{array}$ & ${ }^{40} \mathrm{Ar} /{ }^{39} \mathrm{Ar}$ & Bondarenko et al. (1999) \\
\hline & & zircon & $\begin{array}{l}103.4 \pm 1.7 \\
97.0 \pm 1.1 \\
104.6 \pm 1.0\end{array}$ & $\begin{array}{l}\text { SHRIMP } \\
\mathrm{U}-\mathrm{Pb}\end{array}$ & $\begin{array}{l}\text { Hourigan (2003) } \\
\text { Luchitskaya et al. (2003) }\end{array}$ \\
\hline & $\begin{array}{l}\text { Prybrezhno- } \\
\text { Taigonos }\end{array}$ & biotite & $\begin{array}{l}100.5 \pm 0.4 / 101.1 \pm 0.4 \\
99.03 \pm 0.3 / 101.3 \pm 0.5\end{array}$ & ${ }^{40} \mathrm{Ar} /{ }^{39} \mathrm{Ar}$ & Bondarenko et al. (1999) \\
\hline & & amphibole & $\begin{array}{l}102.9 \pm 2.6 / 103.5 \pm 1.9 \\
101.6 \pm 0.7 / 100.9 \pm 0.6\end{array}$ & & \\
\hline & & zircon & $\begin{array}{l}106.5 \pm 0.9 \\
105.5 \pm 0.9\end{array}$ & $\begin{array}{l}\text { SHRIMP } \\
\mathrm{U}-\mathrm{Pb}\end{array}$ & $\begin{array}{l}\text { Hourigan (2003) } \\
\text { Luchitskaya et al. (2003) }\end{array}$ \\
\hline $\begin{array}{l}\text { Chaun zone of } \\
\text { Verkhoyansk- } \\
\text { Chukotka } \\
\text { fold area }\end{array}$ & Moltykan & $\begin{array}{l}\text { biotite, } \\
\text { amphibole }\end{array}$ & $\begin{array}{l}117 \text { to } 109 \\
\text { (13 determinations) }\end{array}$ & $\mathrm{K}-\mathrm{Ar}$ & Tikhomirov (1998) \\
\hline OCVB & Tanyurer & $\begin{array}{l}\text { amphibole } \\
\text { biotite } \\
\text { plagioclase }\end{array}$ & $\begin{array}{l}79.2 \pm 1.9 \\
79.7 \pm 0.4 \\
82.9 \pm 0.7 \\
77.3 \pm 0.4\end{array}$ & ${ }^{40} \mathrm{Ar} /{ }^{39} \mathrm{Ar}$ & Tikhomirov et al. (2006) \\
\hline
\end{tabular}

rocks are gently dipping terrigenous sediments of Late Jurassic-Early Cretaceous age. By volume, more than $99 \%$ of the pluton consists of monzogranites, granodiorites and quartz monzonites of the main intrusive pulse, and the massive porphyritic rocks with large K-Na-feldspar phenocrysts. The groundmass is mostly medium-grained, composed of andesine-oligoclase $\left(\mathrm{An}_{43-24}\right)$, orthoclase, pale actinolitic amphibole, reddish brown biotite, and quartz. The most typical accessory minerals are apatite, zircon, allanite, sphene, and ilmenite. The pluton is somewhat zoned, with the outer parts composed of relatively mafic quartz monzonites. Sharp contacts between rock varieties have not been found, except for the numerous dikes of porphyritic rocks which compositionally range from diorites and monzonites to leucocratic granites. Zoning of this kind is usual for most granitic plutons of the Chaun tectonic zone.

Bulk rock K-Ar determinations available for the Pevek group yield a wide range of 106 to $74 \mathrm{Ma}$ (Zagruzina, 1977). The whole-rock Rb-Sr isochron age of the Pevek pluton, a neighbour to the Peekiney intrusion, is $147 \pm 25 \mathrm{Ma}$ (Efremov et al., 2000). The only zircon U-Pb determination on granitic rocks of the Pevek group reveals the age of $106 \mathrm{Ma}$ (Miller and Verzhbitsky, 2006), and this date is likely the most solid constraint on the crystallization age of these plutons.

\subsubsection{Moltykan batholith}

The Moltykan batholith is one of the largest granitic plutons of the Chaun zone; its outcrop area is $1630 \mathrm{~km}^{2}$. In plan view, the intrusive body is slightly elongated in a northeasterly direction, across the strike of the principal fold structures of the region (Fig. 2b). It intrudes the Late Triassic clastic sequences and produces a hornfelsic aureole up to $200 \mathrm{~m}$ wide. To the NW and SW, the eroded surface of the batholith is overlain by volcanic strata of the OCVB. Remnants of both Triassic sediments and Late Cretaceous volcanics are present within the Moltykan batholith, indicative of a relatively low depth of the erosional incision. Compositionally, the batholith is dominated by granodiorites and monzogranites, petrographically very similar to those of Peekiney pluton. Between major rock varieties, both sharp contacts and gradual transitions have been documented, so the batholith was likely produced by several major near-simultaneous intrusive pulses.

The age of the Moltykan batholith was determined by the series of $13 \mathrm{~K}$-Ar determinations on mineral separates of amphibole and biotite (Tikhomirov, 1998), which yield ages between 117 and $109 \mathrm{Ma}$ (Table 1). The sufficient internal consistencey of these data suggests that they correspond, in general, to the crystallization age of granites.

\subsubsection{Telekay batholith}

The Telekay batholith is T-shaped in plan view (Fig. 2b). The area of its exposed part is nearly $800 \mathrm{~km}^{2}$. The granitoids cut through and metamorphose terrigenous Late Triassic deposits and Albian molassic unit formed prior to the OCVB initiation (the outcrops of the molasse are too small to be shown on Fig. 2b) (Tikhomirov, 1998). The thickness of the preserved part of the molassic section in the immediate 
neighborhood of the plutons does not exceed $1000 \mathrm{~m}$. Within the region at large, however, it may reach $3 \mathrm{~km}$. Volcanic rocks of the OCVB overlie the eroded surface of the pluton. The northern part of the Telekay batholith is leucogranitic in composition, and its smaller southern part is less silicic, comprising granites and granodiorites. No data on direct relationships between the rocks constituting the northern and southern parts are available; it is likely that they share a fault contact. Petrographic features and age data (see below) imply that the Telekay batholith is of polygenetic character (Tikhomirov, 1998), for which reason its northern and southern parts are hereinafter addressed separately, as constituents of different plutonic complexes.

The massive porphyritic leucogranite of the main emplacement phase of the northern part of the Telekay batholith is composed of quartz, low orthoclase (or microcline), and $\mathrm{An}_{24-10}$ oligoclase rimmed by post magmatic albite and densely colored brown biotite (1 to 3-4\%). Among the accessory minerals, fluorite and tourmaline are widespread, in addition to common apatite, zircon, allanite and ilmenite. The southern part of the Telekay batholith is composed of massive medium-grained amphibole-biotite granite and granodiorite. These consist of quartz, orthoclase, $\mathrm{An}_{40-20}$ plagioclase, bluish green amphibole, and dark brown biotite. Accessory phases are the same as in the granitoids of the Moltykan and Peekiney plutons.

The bulk rock K-Ar ages of the Telekay pluton range between 121 and $81 \mathrm{Ma}$ (Tikhomirov, 1998). The validity of these data is doubtful because these isotopic ages sometimes disagree with directly observed relations between the geologic bodies. The whole-rock $\mathrm{Rb}-\mathrm{Sr}$ isochron for samples from the southern part of the batholith yields 127.0 5 5.3 Ma (Efremov et al., 2000). For the northern part, there are constraints from field observations: leucogranites intrude the Albian molasse, so they must be younger than $112 \mathrm{Ma}$. However, the age of the molassic unit comes from paleobotanic data, which cannot be considered as finally proved. The only reliable age limit for the Telekay batholith is provided by the ${ }^{40} \mathrm{Ar} /{ }^{39} \mathrm{Ar}$ determinations on sanidine from the lowermost OCVB unit which overlies the eroded granites, $88.01 \pm 0.20 \mathrm{Ma}$ (Ispolatov et al., 2004).

\subsection{Granitoids of the OCVB}

The Tanyurer pluton is located in the transitional zone between the Central Chukotka and the Eastern Chukotka segments of the OCVB (Belyi, 1977) (Fig. 2b). Because of poor exposure of the intrusive body, only isolated outcrops of plutonic rocks in the basin of the Tanyurer River within an area of $90 \mathrm{~km}$ by $120 \mathrm{~km}$ are accessible to observation. The pluton has a complex structure and conventionally comprises rocks of Early and Late Cretaceous age (Chubarov and Vyatkin, 1988). The Early Cretaceous granites may be massive or foliated, whereas the Late Cretaceous granites are always massive. Neither whole-rock K-Ar dates, nor the major element data allow discrimination between Early and Late Cretaceous plutons. At present, the only solid evidence of multistage formation of the Tanyurer pluton is its dual relation with volcanic sequences of the OCVB: Late Cretaceous granites crosscut the volcanic strata which, in turn, overlie the eroded surface of Early Cretaceous plutons (Chubarov avd Vyatkin, 1988). In this study, we do not consider the Early Cretaceous constituents of the Tanyurer pluton whose geodynamic position is still not defined properly. They may be related with the Late Jurassic-Early Cretaceous arcs like Pekulney arc (Morozov, 2001) or the Uda-Murgal arc (Parfenov et al., 1993), or with early stages of the OCVB evolution. Our research was concentrated on the northern part of the pluton which definitely intrudes a volcanic pile of the Turonian age. Dikes of both felsic and mafic volcanic rocks crosscut the granites, and we consider this portion of the Tanyurer pluton is coeval to the upper, eroded part of the OCVB section. Our field study has revealed at least seven intrusive pulses, ranging in composition from gabbro to leucogranite. The dominant rock type (roughly $70 \%$ of the exposed area of the pluton) is medium-grained granodiorite, equigranular or porphyritic, composed of quartz (15-25\%), $\mathrm{An}_{40-25}$ plagioclase (40-50\%), orthoclase (15-25\%), and brownish amphibole (7-12\%) in assemblage with reddish brown biotite (5-10\%). In the most mafic varieties, relics of hypersthene and augite are recorded. Of the accessory phases, zircon, apatite, Ti-magnetite, and sphene are widespread; allanite and ilmenite are less common.

${ }^{40} \mathrm{Ar} /{ }^{39} \mathrm{Ar}$ dates on mineral separates (amphibole, biotite and plagioclase) from the massive granodiorites of the Tanyurer pluton display a Campanian age between 83 and $77 \mathrm{Ma}$ (Table 1), consistent with the accepted age of uppermost stratigraphic units of the OCVB (Tikhomirov et al., 2006a, and references therein).

All the plutons studied host microgranular mafic enclaves, which compositionally range from granodiorite to gabbro and monzonite, depending on matrix composition (the enclaves being in all cases somewhat more mafic). Their typical features are (i) the plagioclase and mafic minerals are markedly more euhedral than the quartz and K-Na-feldspar (oxyophitic textures) and (ii) abundant fine acicular apatite. We attribute these enclaves to processes of mechanical mixing of melts of different compositions (Vernon, 1991). Mineral assemblages of microgranular enclaves from the northern Telekay leucogranites were used to estimate the conditions of magma crystallization (see Sect. 8).

Thus, the granitic plutons of the Taigonos peninsula were likely produced within the active margin of the Paleo-Pacific, and emplaced in Albian-Cenomanian time (106 to $97 \mathrm{Ma}$ ). The Chaun zone granites are post-orogenic. Available zircon U-Pb dates on Chaun granites are still sparse (Katkov et al., 2007; Miller and Verzhbitsky, 2006). They correspond to Aptian-Albian time (117 to $106 \mathrm{Ma}$ ) and do not allow the migration of magmatic activity within the tectonic zone to be traced. The whole-rock $\mathrm{Rb}-\mathrm{Sr}$ isochron method sometimes 
yields older dates, $127 \pm 5 \mathrm{Ma}$ for the southern part of the Telekay batholith, and even 147 to $139 \mathrm{Ma}$ for several other local plutons (Efremov et al., 2000). However, the evident disagreement between $\mathrm{Rb}-\mathrm{Sr}$ and zircon $\mathrm{U}-\mathrm{Pb}$ dates for the Pevek group of plutons ( $147 \pm 25$ and $106 \mathrm{Ma}$, respectively) brings some doubts. Certainly, the study of granites of Chaun zone requires more reliable age determinations. Finally, the northern part of the Tanyurer pluton was formed in an active margin environment, like plutons of the Taigonos peninsula, but somewhat later, during the Campanian ( 83 to $77 \mathrm{Ma}$ ).

\section{Analytical methods}

The data on rock compositions were acquired at the chemical-analytical center of GIN RAN (Institute of Geology, Russian Academy of Sciences) and at the chemicalanalytical laboratories of IGEM RAN (Institute of Geology of Ore Deposits, Petrography, Mineralogy, and Geochemistry, Russian Academy of Sciences) and IMGRE (Institute of Mineralogy, Geochemistry, and Crystallochemistry of Rare Elements, Russian Academy of Sciences). Major element contents were measured by the wet chemistry method and XRF; trace elements, by XRF (on a ARF 6 quantometer and a Philips PW2400 spectrometer); and REE, U, and Th, by INAA on a gamma spectrometer with a GEM-30185 Ortech semiconductor detector. Routine techniques ensuring standard precision were used (Zolotarev and Margolin, 1983; Anonymous, 2005).

The microprobe analyses were carried out on transparent polished thin sections. In minor amounts (8 of 127 analyses), epoxy-mounted grains from monomineral separates were used. For detailed study, we selected 2-3 representative samples from the main emplacement phases of each particular pluton; composition of minerals from microgranular enclaves in the leucogranite of the northern part of the Telekay intrusion were studied as well. Microprobe analyses of thin sections were performed at two laboratories of microanalysis at Moscow State University: at the Petrology Department (on a Camscan 4DV electron microscope with the Link AN10000 detector; analysts E. V. Guseva and N. N. Korotaeva) and the Mineralogy Department (on a CAMEBAX SX-50 probe, analyst N. N. Kononkova). Biotites from monomineral separates were studied at the IMGRE microprobe laboratory (on a Camebax Microbeam instrument; analyst I. M. Kulikova).

\section{Geochemical signatures of the granitoids}

\subsection{Major elements}

The new analytical data are listed in Table 2 and depicted on diagrams (Figs. 3-6). In addition, we used the major element analyses from mineral exploration reports (180 analyses), plotted on Figs. 3 and 4. The latter analyses were performed at the Central Laboratory of SVPGO State Enterprise (Magadan, Russia) in 1987-1992 by the wet chemical methods. The analyses and the description of analytical methods are available from authors upon request.

The greatest diversity of igneous rocks is displayed by the Tanyurer pluton, comprising the full rock spectrum from gabbro through diorites and granodiorites to leucogranites (Figs. 3 and 4). The rocks of the Prybrezhny Taigonos belt are represented by diorites, quartz diorites, tonalites, with minor granodiorites. The rest of the intrusions are dominated by monzogranites and granodiorites, with minor quartz monzonites and quartz monzodiorites. Samples from the Chaun zone plutons are relatively uniform and lack distinct differentiation trends (Figs. 3 and 4). The alkaline metals proved to be the best discriminants among major elements. The $\mathrm{K} / \mathrm{Na}$ ratio and total alkalinity of the granodiorites increase systematically through the range of plutons: Prybrezhny Taigonos $\rightarrow$ Eastern Taigonos $\rightarrow$ Tanyurer $\rightarrow$ southern part of the Telekay pluton $\rightarrow$ other intrusions of the Chaun zone (Fig. 4a, b). Average values of the $\mathrm{K} /(\mathrm{K}+\mathrm{Na})$ index range from 0.1 (Prybrezhny Taigonos belt) to 0.54 (Peekiney intrusion). Granitoids of the Prybrezhny Taigonos belt have the highest $\mathrm{CaO}$ content (Fig. 3) and, accordingly, the lowest alumina content in this population (Fig. 4c). In the majority of the rest of the plutons, the average alumina saturation index $\mathrm{ASI}=\mathrm{Al} /(\mathrm{K}+\mathrm{Na}+2 \mathrm{Ca})$ ratio is close to unity and exceeds 1.05 only in the rocks of the Peekiney intrusion and of the northern part of the Telekay pluton (Fig. 4c).

\subsection{Trace elements}

Trace element composition of the rocks studied (Figs. 5 and 6 ) is much more diverse than their major oxide contents. Analysis of the acquired data enables us to subdivide the plutons into five groups: (i) Prybrezhny Taigonos; (ii) Eastern Taigonos; (iii) Tanyurer and the southern part of the Telekay batholith; (iv) Peekiney and Moltykan; and (v) the northern part of the Telekay batholith. The groups are enumerated in the order of general enrichment of the rocks in the incompatible lithophile elements, whose contents are persistently correlative with $\mathrm{K}_{2} \mathrm{O}$ abundances, much more so than with silica contents (Fig. 6).

The most depleted granitoids in this population are those of the Prybrezhny Taigonos belt. They are distinguished by the lowest $\mathrm{La} / \mathrm{Yb}$ ratios, relatively weak $\mathrm{Ta}-\mathrm{Nb}$ minima, and elevated contents of $\mathrm{Y}$ and heavy REEs, imparting an overall positive slope to the spidergrams (Fig. 5). Trace-element composition of the rocks of the Prybrezhny Taigonos belt is close to the inferred average composition of the lower continental crust (Taylor and McLennan, 1985). In the granitoids of the Eastern Taigonos pluton, LILE contents are somewhat higher, and their trace element ratios are widely variable (Fig. 6). A commom feature of all the rocks studied from the Taigonos Peninsula is the variability of $\mathrm{Sr}$ (Fig. 5a) and Eu contents (Figs. 5c and 6d), likely resulting from the 
Table 2. Major (wt.\%) and trace elements (ppm) of Cretaceous granitoids from Chaun tectonic zone and Taigonos Peninsula, NE Asia.

\begin{tabular}{|c|c|c|c|c|c|c|c|c|c|c|c|c|c|c|c|c|c|}
\hline No & 1 & 2 & 3 & 4 & 5 & 6 & 7 & 8 & 9 & 10 & 11 & 12 & 13 & 14 & 15 & 16 & 17 \\
\hline & & & Tan & Tan & Tan & Peek & Peek & Peek & Peek & Mol & Mol & Tels & Teln & Teln & Teln & ET & ET \\
\hline No sam. & $2458 \mathrm{~b} / 02$ & $2465 \mathrm{a} / 02$ & $2481 \mathrm{a} / 02$ & $2485 \mathrm{a} / 02$ & Ugl1a/02 & $5 \mathrm{~g}$ & $5 / 3$ & $7 / 5$ & $8 \mathrm{a}$ & $8277 / \mathrm{Ml}$ & Ml-11 & 7797-I & $3607 a$ & $7581 a$ & $7589 a$ & $222 / 6$ & $222 / 7$ \\
\hline $\mathrm{SiO}_{2}$ & 68.87 & 61.13 & 49.89 & 58.3 & 70.35 & 63.3 & 63.58 & 65.25 & 61.92 & 65.78 & 66.14 & 69.43 & 75.56 & n.d. & n.d. & 67.33 & 63.57 \\
\hline $\mathrm{TiO}_{2}$ & 0.37 & 0.74 & 0.56 & 0.84 & 0.31 & 0.7 & 0.7 & 0.58 & 0.73 & 0.52 & 0.59 & 0.4 & 0.1 & n.d. & n.d. & 0.6 & 0.56 \\
\hline $\mathrm{Al}_{2} \mathrm{O}_{3}$ & 14.18 & 16.22 & 21.62 & 16.18 & 14.03 & 16.51 & 16.31 & 16.31 & 16.91 & 16.34 & 15.35 & 14.41 & 12.8 & n.d. & n.d. & 15.24 & 16.51 \\
\hline $\mathrm{Fe}_{2} \mathrm{O}_{3}$ & 2.35 & 3.18 & 4.17 & 4.74 & 1.52 & 4.47 & 4.55 & 3.66 & 4.82 & 3.63 & 3.93 & 3.66 & 1.5 & n.d. & n.d. & 1.28 & 2.89 \\
\hline $\mathrm{FeO}$ & 1.63 & 3.27 & 2.66 & 3.8 & 1.43 & n.d. & n.d. & n.d. & n.d. & n.d. & n.d. & n.d. & n.d. & n.d. & n.d. & 3.23 & 2.35 \\
\hline $\mathrm{MnO}$ & 0.08 & 0.12 & 0.09 & 0.15 & 0.07 & 0.062 & 0.069 & 0.057 & 0.076 & 0.063 & 0.061 & 0.047 & 0.022 & n.d. & n.d. & 0.15 & 0.07 \\
\hline $\mathrm{MgO}$ & 1.75 & 2.62 & 3.98 & 2.59 & 1.21 & 2.14 & 2.18 & 1.44 & 2.03 & 1.1 & 1.97 & 0.93 & 0.12 & n.d. & n.d. & 1.44 & 1.59 \\
\hline $\mathrm{CaO}$ & 2.68 & 4.93 & 10.54 & 6.16 & 2.06 & 3.67 & 3.21 & 2.74 & 3.86 & 2.27 & 2.74 & 1.97 & 0.24 & n.d. & n.d. & 5.02 & 5.49 \\
\hline $\mathrm{Na}_{2} \mathrm{O}$ & 4.13 & 3.9 & 2.35 & 3.65 & 3.79 & 2.93 & 2.94 & 3.12 & 3.34 & 3.37 & 2.99 & 3.32 & 3.46 & n.d. & n.d. & 3.93 & 4.06 \\
\hline $\mathrm{K}_{2} \mathrm{O}$ & 2.87 & 2.78 & 1.41 & 2 & 4.38 & 4.7 & 4.74 & 5.58 & 5.07 & 5.52 & 4.56 & 3.55 & 5.06 & n.d. & n.d. & 1.31 & 1.97 \\
\hline $\mathrm{P}_{2} \mathrm{O}_{5}$ & 0.12 & 0.2 & 0.14 & 0.19 & 0.08 & 0.216 & 0.228 & 0.133 & 0.185 & 0.15 & 0.161 & 0.103 & 0.015 & n.d. & n.d. & 0.13 & 0.12 \\
\hline LOI & 0.8 & 1 & 2.32 & 1.21 & 0.65 & 0.55 & 0.72 & 0.42 & 0.25 & 0.46 & 0.8 & 1.17 & 0.63 & n.d. & n.d. & 0.82 & 0.71 \\
\hline Total & 99.83 & 100.09 & 99.73 & 99.81 & 99.88 & 99.25 & 99.23 & 99.29 & 99.19 & 99.203 & 99.29 & 98.99 & 99.51 & - & - & 100.5 & 99.89 \\
\hline $\mathrm{Rb}$ & 85 & 76 & 67 & 63 & 140 & 225 & 231 & 272 & 247 & 273 & 235 & 120 & 480 & 298 & 456.5 & 17 & 38 \\
\hline $\mathrm{Ba}$ & 800 & 1200 & 900 & 1500 & 700 & 1200 & 1170 & 880 & 1120 & 1330 & 930 & 1080 & 90 & n.d. & n.d. & 750 & 610 \\
\hline Th & n.d. & n.d. & n.d. & n.d. & n.d. & 29.18 & 36.11 & 34.54 & 25.3 & 25.119 & 31.75 & 10.34 & 38.41 & 28 & 22 & 2.4 & n.d. \\
\hline $\mathrm{U}$ & n.d. & n.d. & n.d. & n.d. & n.d. & 3.398 & 6.191 & 2.667 & 6.095 & 4.123 & 4.66 & 4.072 & 4.91 & 1.7 & 1.9 & n.d. & n.d. \\
\hline $\mathrm{Ta}$ & n.d. & n.d. & n.d. & n.d. & n.d. & 1.363 & 1.444 & 1.547 & 1.507 & 1.7276 & 1.256 & 0.517 & 2.265 & 4 & 5 & n.d. & n.d. \\
\hline $\mathrm{Nb}$ & 7 & 7.1 & 4 & 5.4 & 8.1 & 19 & 19 & 25 & 20 & 20 & 17 & 8 & 19 & 18.5 & 21 & 4 & 3.6 \\
\hline $\mathrm{Hf}$ & n.d. & n.d. & n.d. & n.d. & n.d. & 5.658 & 6.487 & 4.597 & 6.531 & 6.263 & 5.312 & 4.459 & 3.534 & n.d. & n.d. & n.d. & n.d. \\
\hline $\mathrm{Zr}$ & 110 & 210 & 68 & 140 & 130 & 234 & 210 & 169 & 193 & 196 & 169 & 165 & 109 & 157 & 96 & 120 & 140 \\
\hline $\mathrm{Y}$ & 15 & 25 & 9.5 & 21 & 16 & 26 & 30 & 28 & 31 & 33 & 29 & 27 & 100 & 54 & 75 & 10 & 15 \\
\hline $\mathrm{Sr}$ & 290 & 420 & 630 & 480 & 210 & 490 & 460 & 398 & 498 & 361 & 365 & 431 & 20 & 20.5 & 12.5 & 450 & 510 \\
\hline $\mathrm{La}$ & 14 & 21 & 9.7 & 21 & 32 & 47.37 & 61.29 & 53.83 & 52.87 & 54.594 & 75.42 & 14.99 & 32.89 & n.d. & n.d. & 12 & 12 \\
\hline $\mathrm{Ce}$ & 34 & 48 & 21 & 48 & 67 & 100.5 & 111 & 104.8 & 97.95 & 105.73 & 139.3 & 34.43 & 61.94 & n.d. & n.d. & 26 & 33 \\
\hline $\mathrm{Nd}$ & 14 & 25 & 11 & 22 & 26 & 36.15 & 43.29 & 36.07 & 39.4 & 43.693 & 53.76 & 13.98 & 37.73 & n.d. & n.d. & 11 & 24 \\
\hline $\mathrm{Sm}$ & 2.6 & 4.7 & 2.6 & 4.2 & 3.7 & 6.819 & 8.777 & 6.409 & 7.902 & 8.6698 & 9.501 & 3.266 & 10.99 & n.d. & n.d. & 2.3 & 3.1 \\
\hline $\mathrm{Eu}$ & 0.66 & 1 & 0.77 & 1.2 & 0.58 & 1.405 & 1.572 & 1.208 & 1.647 & 1.6297 & 1.512 & 0.737 & 0.136 & n.d. & n.d. & 0.68 & 0.8 \\
\hline $\mathrm{Tb}$ & 0.45 & 0.69 & 0.39 & 0.68 & 0.48 & 1.319 & 0.868 & 0.821 & 0.985 & 1.318 & 0.971 & 0.64 & 2.976 & n.d. & n.d. & 0.29 & 0.41 \\
\hline $\mathrm{Yb}$ & 1.6 & 2.3 & 1.1 & 2.2 & 2 & 1.844 & 2.447 & 2 & 2.536 & 2.7516 & 2.276 & 2.012 & 9.148 & n.d. & n.d. & 1.2 & 1.2 \\
\hline $\mathrm{Lu}$ & 0.23 & 0.37 & 0.18 & 0.35 & 0.32 & 0.232 & 0.25 & 0.232 & 0.299 & 0.3392 & 0.226 & 0.325 & 1.24 & n.d. & n.d. & 0.18 & 0.19 \\
\hline \multirow[t]{2}{*}{ No } & 18 & 19 & 20 & 21 & 22 & 23 & 24 & 25 & 26 & 27 & 28 & 29 & 30 & 31 & 32 & 33 & 34 \\
\hline & ET & ET & ET & ET & ET & ET & ET & ET & ET & PT & PT & PT & PT & PT & PT & PT & PT \\
\hline No sam. & $223 / 1$ & $223 / 2$ & $219 / 2$ & $219 / 9$ & $219 / 11$ & $219 / 8$ & $219 / 12$ & $221 / 1$ & $221 / 7$ & $210 / 3$ & $206 / 1$ & 209 & $208 / 10$ & $\mathrm{~m}-208$ & $210 / 5$ & $210 / 4$ & $208 / 6$ \\
\hline $\mathrm{SiO}_{2}$ & 63.49 & 63.42 & 63.72 & 66.52 & 70.06 & 71.26 & 75.13 & 76.05 & 58.66 & 58.62 & 58.75 & 60.11 & 63.98 & 64.4 & 66.33 & 67.07 & 59.17 \\
\hline $\mathrm{TiO}_{2}$ & 0.83 & 0.62 & 0.92 & 0.58 & 0.64 & 0.43 & 0.16 & 0.25 & 1.36 & 0.77 & 0.82 & 0.58 & 1.02 & 1.02 & 0.42 & 0.63 & 1.42 \\
\hline $\mathrm{Al}_{2} \mathrm{O}_{3}$ & 15.62 & 16.09 & 15.62 & 14.6 & 13.56 & 13.67 & 13.28 & 12.57 & 17.95 & 17.02 & 15.58 & 15.4 & 16.2 & 15.48 & 14.94 & 15.01 & 15.68 \\
\hline $\mathrm{Fe}_{2} \mathrm{O}_{3}$ & 2.21 & 2.54 & 2.61 & 2.27 & 1.2 & 2.44 & 0.59 & 1.18 & 2.16 & 1.89 & 1.97 & 4.51 & 0.61 & 1.19 & 2.33 & 0.67 & 1.15 \\
\hline $\mathrm{FeO}$ & 2.42 & 2.27 & 2.14 & 1.85 & 1.51 & 0.64 & 0.49 & 0.37 & 4.2 & 5.49 & 6.29 & 3.84 & 4.58 & 4.49 & 2.43 & 3.16 & 7 \\
\hline $\mathrm{MnO}$ & 0.06 & 0.07 & 0.06 & 0.03 & 0.05 & 0.03 & 0.01 & 0.01 & 0.18 & 0.21 & 0.18 & 0.03 & 0.15 & 0.14 & 0.06 & 0.12 & 0.35 \\
\hline $\mathrm{MgO}$ & 2.96 & 2.24 & 3.09 & 2.19 & 1 & 0.25 & 0.4 & 0.41 & 2.78 & 2.82 & 3.61 & 2.75 & 1.93 & 2.14 & 0.99 & 1.1 & 3.18 \\
\hline $\mathrm{CaO}$ & 5.44 & 5.66 & 4.71 & 3.37 & 3.84 & 2.91 & 0.55 & 0.65 & 5.95 & 6.65 & 7.53 & 6.74 & 5.15 & 5.26 & 5.47 & 5.6 & 4.9 \\
\hline $\mathrm{Na}_{2} \mathrm{O}$ & 4.37 & 3.89 & 4.37 & 4.37 & 4.49 & 3.98 & 4.18 & 4.18 & 5.18 & 4.12 & 3.6 & 4.18 & 4.28 & 4.37 & 4.87 & 4.4 & 4.57 \\
\hline $\mathrm{K}_{2} \mathrm{O}$ & 1.96 & 1.88 & 2.14 & 2.72 & 3.1 & 3.37 & 3.93 & 4.02 & 0.99 & 0.69 & 0.73 & 0.85 & 1.3 & 1.25 & 0.83 & 0.81 & 1.5 \\
\hline $\mathrm{P}_{2} \mathrm{O}_{5}$ & 0.08 & 0.12 & 0.01 & 0.06 & 0.09 & 0.02 & 0.007 & 0.01 & 0.18 & 0.15 & 0.08 & 0.004 & 0.2 & 0.14 & 0.04 & 0.09 & 0.19 \\
\hline LOI & 0.7 & 0.51 & 0.89 & 0.92 & 0.065 & 0.55 & 0.69 & 0.4 & 0.84 & 1.45 & 0.84 & 0.92 & 0.74 & 0.55 & 1.37 & 1.18 & 0.85 \\
\hline Total & 100.14 & 99.31 & 100.28 & 99.48 & 99.605 & 99.55 & 99.42 & 100.1 & 100.4 & 99.88 & 99.98 & 99.91 & 100.1 & 100.4 & 100.1 & 99.84 & 99.96 \\
\hline $\mathrm{Rb}$ & 40 & 40 & 55 & 77 & 76 & 93 & 97 & 97 & 19 & 18 & 20 & 22 & 36 & 33 & 22 & 18 & 42 \\
\hline $\mathrm{Ba}$ & 650 & 620 & 590 & 620 & 600 & 700 & 790 & 770 & 260 & 140 & 160 & 580 & 300 & 230 & 160 & 160 & 310 \\
\hline Th & n.d. & n.d. & 17 & 12 & n.d. & 20 & 11 & 12 & 0.9 & n.d. & n.d. & 2.2 & 2.4 & 3.6 & 1.4 & n.d. & 3.5 \\
\hline $\mathrm{U}$ & n.d. & n.d. & n.d. & n.d. & n.d. & n.d. & n.d. & n.d. & n.d. & n.d. & n.d. & n.d. & n.d. & n.d. & n.d. & n.d. & n.d. \\
\hline $\mathrm{Ta}$ & n.d. & n.d. & 0.44 & 0.36 & n.d. & 0.42 & 0.58 & 0.5 & 0.2 & n.d. & n.d. & 0.11 & 0.18 & 0.2 & 0.15 & n.d. & 0.3 \\
\hline $\mathrm{Nb}$ & 2.4 & 3.2 & 4.5 & 4.8 & 4.6 & 5.3 & 6.7 & 6.8 & 2.8 & 1.3 & 3.4 & 4.9 & 4.5 & 6 & 3.7 & 2.5 & 5.6 \\
\hline $\mathrm{Hf}$ & n.d. & n.d. & 5.6 & 3.5 & n.d. & 4.6 & 3.3 & 3.6 & 3.3 & n.d. & n.d. & 5.4 & 5.8 & 6.1 & 3.3 & n.d. & 4.9 \\
\hline $\mathrm{Zr}$ & 92 & 110 & 130 & 100 & 110 & 98 & 85 & 68 & 91 & 84 & 96 & 180 & 170 & 190 & 86 & 86 & 160 \\
\hline $\mathrm{Y}$ & 7.4 & 8.6 & 14 & 12 & 10 & 11 & 9.4 & 9.6 & 15 & 18 & 25 & 41 & 25 & 36 & 16 & 20 & 27 \\
\hline $\mathrm{Sr}$ & 580 & 580 & 370 & 290 & 250 & 200 & 97 & 100 & 470 & 180 & 140 & 180 & 220 & 180 & 170 & 150 & 230 \\
\hline $\mathrm{La}$ & 10 & 9.7 & 15 & n.d. & n.d. & 16 & 10 & 12 & 6 & n.d. & 6.9 & 9.1 & 7.5 & 11 & 5 & 10 & 14 \\
\hline $\mathrm{Ce}$ & 23 & 20 & 32 & n.d. & n.d. & 35 & 24 & 25 & 14 & n.d. & 16 & 22 & 17 & 25 & 14 & 22 & 37 \\
\hline $\mathrm{Nd}$ & 11 & 9.5 & 15 & n.d. & n.d. & 12 & 9 & 9 & 8.4 & n.d. & 11 & 16 & 11 & 16 & 7.4 & 13 & 20 \\
\hline $\mathrm{Sm}$ & 1.9 & 1.8 & 3.2 & n.d. & n.d. & 1.9 & 1.4 & 1.4 & 2.1 & n.d. & 3.5 & 4.9 & 2.8 & 4.2 & 2.1 & 3.7 & 4.5 \\
\hline $\mathrm{Eu}$ & 0.6 & 0.61 & 0.75 & n.d. & n.d. & 0.39 & 0.25 & 0.28 & 0.88 & n.d. & 0.87 & 1.1 & 0.95 & 1.1 & 0.79 & 0.89 & 1.8 \\
\hline $\mathrm{Tb}$ & 0.22 & 0.24 & 0.43 & n.d. & n.d. & 0.17 & 0.24 & 0.2 & 0.4 & n.d. & 0.74 & 1 & 0.59 & 0.86 & 0.5 & 0.63 & 0.74 \\
\hline $\mathrm{Yb}$ & 0.78 & 0.8 & 1.3 & n.d. & n.d. & 0.71 & 0.92 & 0.86 & 1.6 & n.d. & 2.8 & 4.2 & 2.2 & 3.6 & 2 & 2.4 & 3.2 \\
\hline $\mathrm{Lu}$ & 0.13 & 0.13 & 0.19 & n.d. & n.d. & 0.13 & 0.15 & 0.16 & 0.26 & n.d. & 0.44 & 0.68 & 0.34 & 0.61 & 0.35 & 0.41 & 0.54 \\
\hline
\end{tabular}

Major element abundances are given in wt $\%$, and trace elements, in ppm.

1-5 - Tanyurer batholith; 6-9 - Peekiney pluton; 10-11 - Moltykan batholith; 12-15 - Telekay batholith (12 - southern part, 13-15 - northern part); 16-26 - Eastern Taigonos batholith; 27-34 - Prybrezhny Taigonos pluton.

Analyses 1-5 and 16-34 were obtained at the chemical-analytical center of GIN RAN. Major element contents were measured by the wet chemistry method; Th and REE, by INAA (analyst S.M. Lyapunov), and the rest of the trace elements, by XRF. Analyses 6-13 were carried out at the chemical-analytical laboratory of IGEM RAN. The contents of U, Th, and REE were measured by INAA (analyst A. L. Kerzin), and the rest of the elements, by XRF (analysts T. M. Marchenko and A. I. Yakushev). Analyses 14-15 were obtained at the chemical-analytical laboratory of IMGRE by XRF; analyst R. L. Barinsky. 

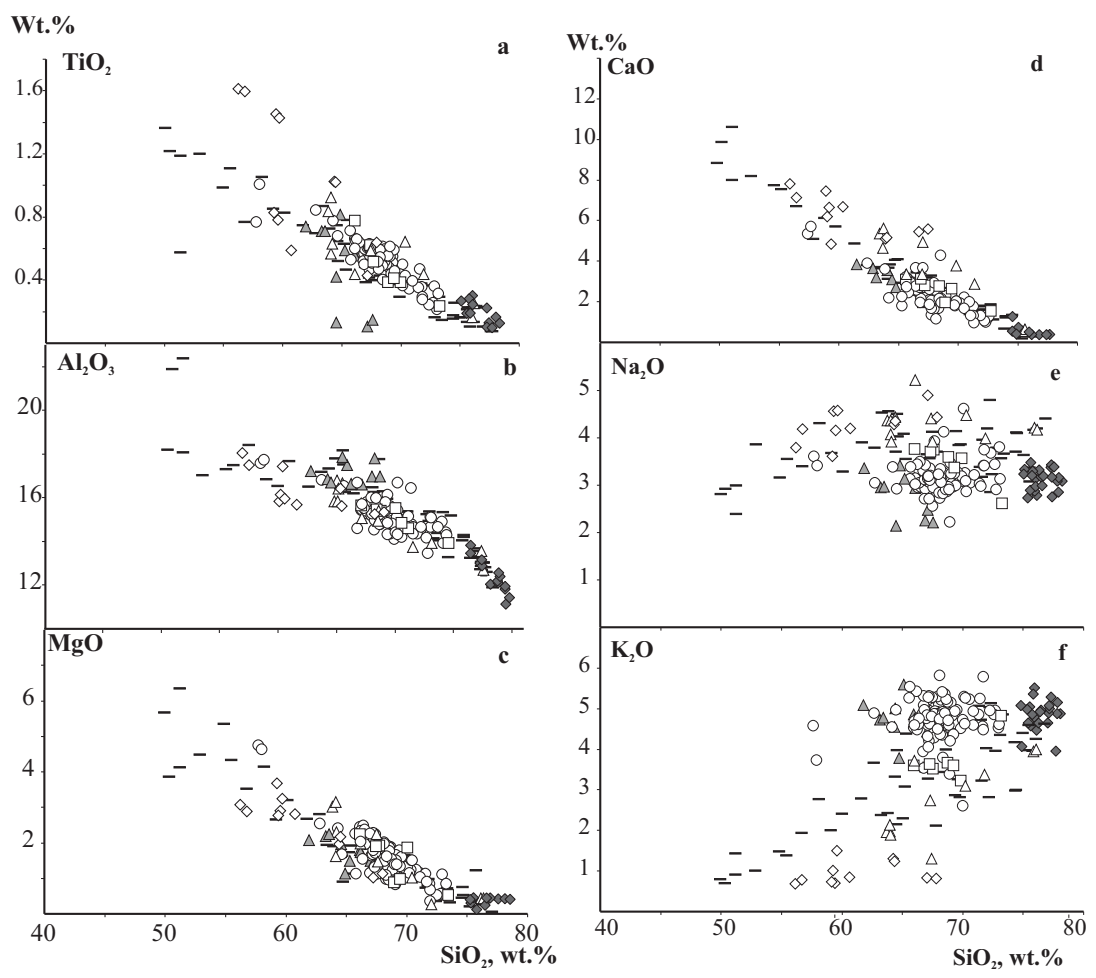

Plutons

$$
\begin{array}{ll}
- \text { Tanyurer } & \square \text { Telekay, southern part } \\
\Delta \text { Peekiney } & \diamond \text { Telekay, northern part } \\
\circ \text { Moltykan } & \triangle \text { Eastern Taigonos } \\
& \diamond \text { Prybrezhny Taigonos }
\end{array}
$$

Fig. 3. Harker diagrams (wt $\%$ of oxides vs. $\mathrm{SiO}_{2}$ ) for the plutons studied.

significant fractionation of plagioclase. The Tanyurer pluton and the southern part of the Telekay pluton display moderate contents of the incompatible elements. They are close in composition to the upper continental crust average (Fig. 5). Gabbros of the early emplacement phases of the Tanyurer intrusion are chemically similar to the granitoids, differing from them by their relative depletion and lack of Eu anomaly (Fig. 5b, d). The Peekiney and Moltykan plutons are relatively enriched in LILE and LREE. Their $\mathrm{La} / \mathrm{Yb}$ ratio is twice higher than the average value for the upper continental crust. However, their spidergrams retain the $\mathrm{Nb}, \mathrm{Ta}$, and $\mathrm{P}$ minima, common to all the rocks studied (Fig. 5). The rocks of the northern part of the Telekay pluton stand alone due to the geochemical signatures inherent of some leucogranites and alaskites. High contents of the majority of incompatible lithophile elements in these rocks are combined with strong $\mathrm{Ba}, \mathrm{Sr}, \mathrm{P}$, and Eu minima and the considerable enrichment in HREE (Fig. 5b, d).

On the discriminant diagram (Fig. 7), most of the studied plutons plot in the region of granitoids of active continental margins. Leucogranites of the northern part of the Telekay intrusion are close to post-orogenic intraplate rocks. Position of the Peekiney and Moltykan plutons is less clear: their geo- chemical signatures are transitional between granitoids from supra-subduction zones, postcollisional uplifts, and late orogenic settings.

\section{Mineral compositions}

In the course of our study, we focused mainly on the composition of the amphibole, biotite, and plagioclase from the granitoids, as well as the oxide accessory phases: Timagnetite and ilmenite. The K-Na-feldspars from the studied rock have not preserved any traces of magmatic zoning, and all of them have undergone various degrees of subsolvus exsolution and/or hydrothermal alteration. This makes them of little use in trying to restore the primary crystallization conditions. The microprobe data with the results of their recalculation are listed in Tables 3-5 and depicted in Figs. 8-11.

\subsection{Amphibole}

Minerals of the amphibole group occur in the rocks of the main intrusive pulses of all granitoids studied, except for the northern part of the Telekay pluton, where they are found only in the mafic enclaves. In the amphibole composition, the 


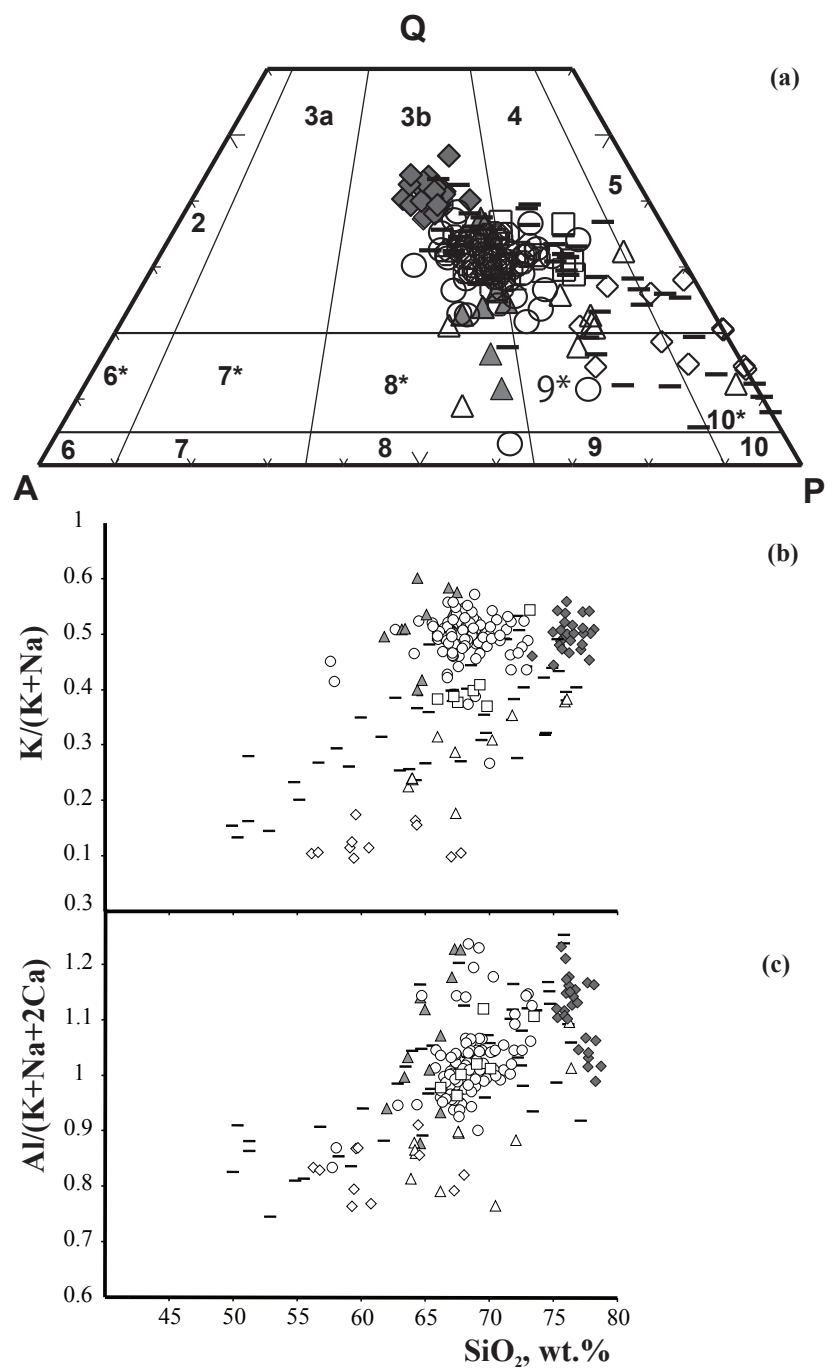

Fig. 4. QAP diagrams (Le Maitre, 1989), $\mathrm{K} /\left(\mathrm{K}+\mathrm{Na}\right.$ ) vs. $\mathrm{SiO}_{2}$, and $\mathrm{Al} /(\mathrm{Na}+\mathrm{K}+2 \mathrm{Ca})$ vs. $\mathrm{SiO}_{2}$ for the plutons studied. Symbols as in Fig. 3. Compositional fields of plutonic rocks: 2 - alkali feldspar granite, $3 \mathrm{a}$ - syeno-granite, $3 \mathrm{~b}$ - monzogranite, 4 - granodiorite, 5 - tonalite, 6 - alkali feldspar syenite, $6^{*}$ - quartz alkali feldspar syenite, 7 - syenite, $7^{*}$ - quartz syenite, 8 - monzonite, $8^{*}$ - quartz monzonite, 9 - monzodiorite/monzogabbro, $9^{*}$ - quartz monzodiorite/quartz monzogabbro, 10 - diorite-gabbro-anorthosite, $10^{*}$ quartz diorite/quartz gabbro/quartz anorthosite.

kaersutite-hastingsite component accounts for $20-30 \%$, the rest consisting of edenite and hornblende in various proportions (Table 3). Also common are pale colored amphiboles, largely affected by postmagmatic processes and containing, instead of kaersutite, up to $35 \%$ tremolite-actinolite end member (e.g., all the amphiboles analysed in the Peekiney and Moltykan intrusions). The diagram in Fig. 8a further supports the assumption of wide-spread isomorphism $\mathrm{Si}^{4+} \rightarrow \mathrm{Al}^{3+}+(\mathrm{K}, \mathrm{Na})^{+}$, linking the tremolite-actinolite and edenite end members. The "tschermakite" isomorphism $\mathrm{Si}^{4+}+(\mathrm{Fe}, \mathrm{Mg})^{2+} \rightarrow 2 \mathrm{Al}^{3+}$ also takes place, but it is not so distinct (Fig. 8). Despite the fact that in a number of thin sections optical observations have recorded relics of igneous (oscillatory) zoning in the amphibole, the compositional variations within individual grains and within a single sample do not exceed the analytical error. However, amphiboles may show perceptible variations between different parts of the intrusive bodies. The most variable chemical parameter of the amphiboles is their Mg\# (Fig. 8a-c), ranging from 0.7 (as in the granodiorite of the Eastern Taigonos pluton) to 0.2 (as in the microgranular enclaves from the northern part of the Telekay pluton). With increasing $\mathrm{Fe} / \mathrm{Mg}$ ratio of the amphiboles, their $\mathrm{Al}, \mathrm{Ti}, \mathrm{Na}$, and $\mathrm{K}$ contents increase. This dependency may be enhanced by the chemical effect of actinolitization.

\subsection{Biotite}

Biotite, the most widespread Fe-Mg silicate of the granitoids, is present in all samples studied. All biotites lack apparent zoning, although there are evidences of its protracted crystallization (in particular, the paragenesis with plagioclases of various composition). Just as with the amphibole, the variations of biotite composition on a sample scale are insignificant, while on the scale of an intrusion the variations may be considerable. The biotite $\mathrm{Mg} \#$ ranges from 0.55 to 0.2 , with no clear correlation with alumina content (Table 4, Fig. 9a) and with a strong positive correlation with the amphibole Mg\# (Fig. 9b). The biotites from the Prybrezhny Taigonos belt and the southern part of the Telekay pluton have the most alumina-rich biotites (1.3-1.4 a.f.u. of $\mathrm{Al})$, and the biotites from the northern part of the Telekay pluton are the most alumina-poor (1.15-1.18 a.f.u.). Micas from the mafic enclaves and the granitoid matrix are identical, despite the differences in the bulk rock compositions (Fig. 9a).

\subsection{Plagioclase}

Plagioclase, judging by its well preserved oscillatory zoning, is more resistant to late magmatic homogenization than the biotite. Plagioclases from the northern part of the Telekay intrusion are represented by oligoclase-albite $\left(\mathrm{An}_{27-3}\right)$, and in all the other plutons, by andesine-oligoclase $\left(\mathrm{An}_{47-14}\right)$ (Fig. 10). The widest range of plagioclase compositions within an individual thin section, if not consider the posmagmatic albite rims, is $\mathrm{An}_{28-17}$. The zoning is always direct (i.e., Ca contents are decreasing from cores to rims), with insignificant oscillations. The differences between the studied plutons in terms of the average plagioclase composition are less significant than in terms of the mafic mineral compositions. The anorthite component of the plagioclases systematically decreases with increasing silica content of the rocks (Fig. 10). Plagioclase of variable composition (except the most calcic $\mathrm{An}_{47-40}$, which probably represents the liquidus phase) forms intergrowths with the amphibole and biotite. 


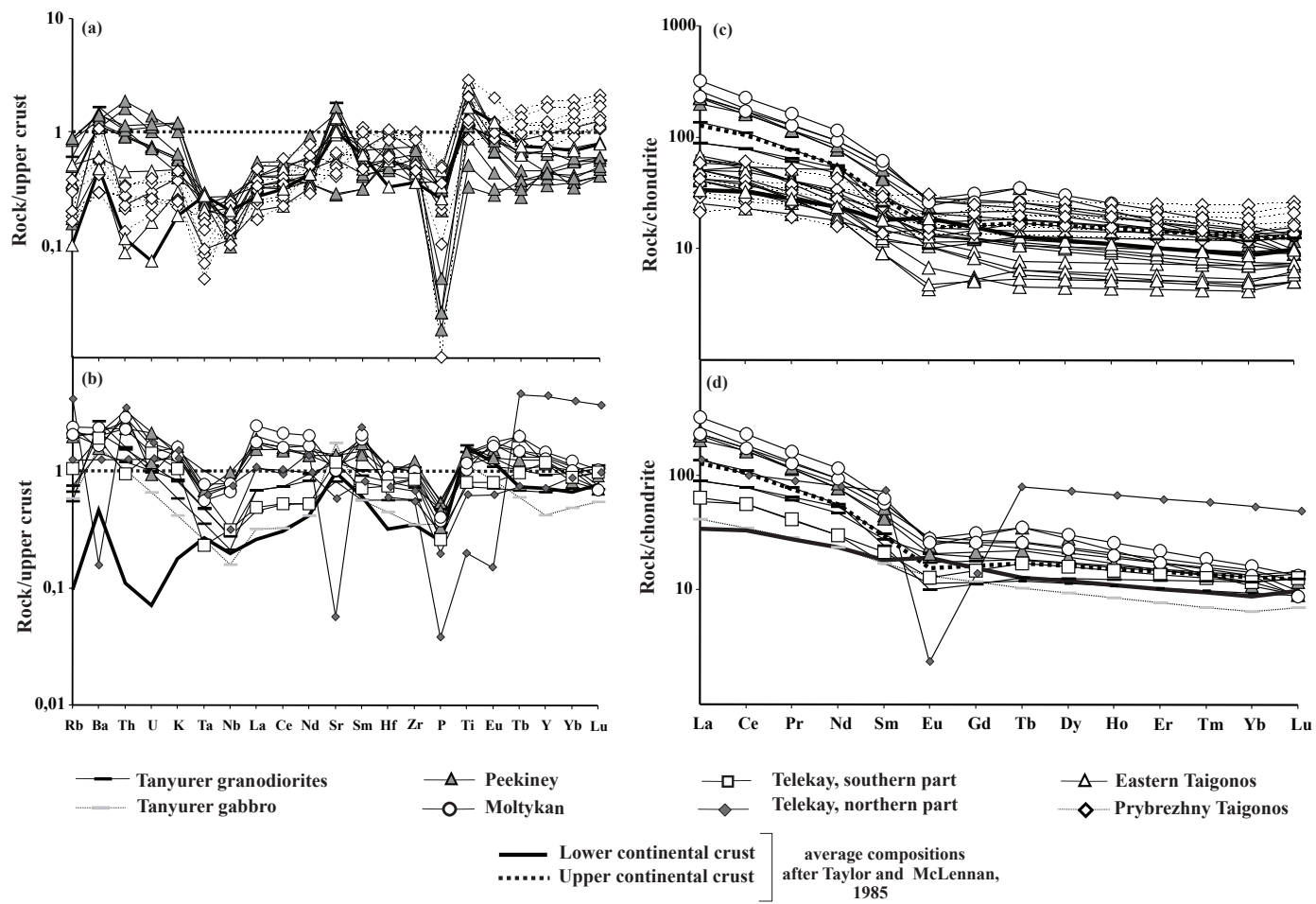

Fig. 5. Spidergrams (a, b) and REE diagrams (c, d) for the plutons studied (rock compositions normalized to the upper crust; Taylor and McLennan, 1985; and Cl chondrite; Sun and McDonough, 1989).

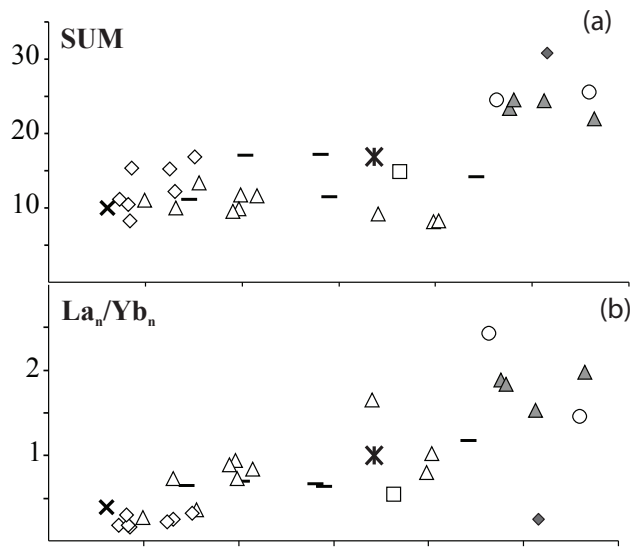

$\mathrm{K}_{2} \mathrm{O}$, wt.\%

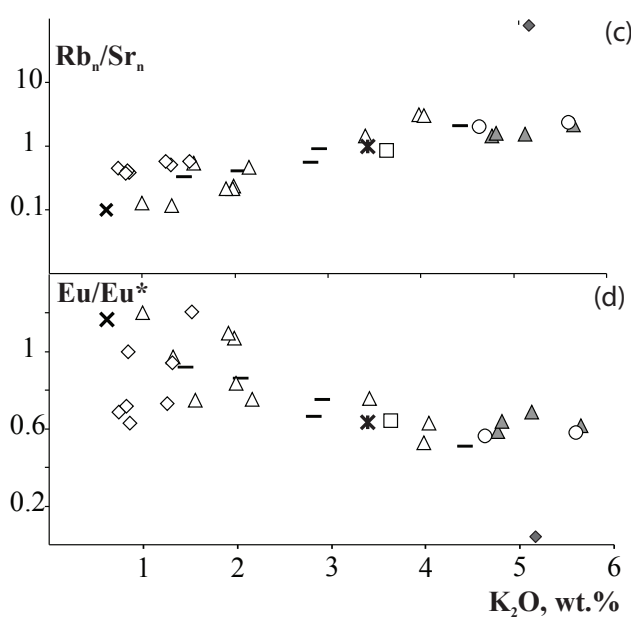

* upper continental crust
$\times$ lower continental crust average compositions after Taylor and Mclennan, 1985

Fig. 6. Trace element variation diagrams for Cretaceous granitoids of NE Asia (element abundances normalized to the upper continental crust composition; Taylor and McLennan, 1985).

SUM - sum total of values normalized to the upper continental crust for the elements included in the spidergrams (Fig. 5a and b). Only those elements analyzed in all the samples are included. Average compositions of lower and upper continental crust (Taylor and McLennan, 1985) are shown for the reference. Other symbols as in Fig. 3. 
Table 3. Amphibole composition from Cretaceous granitoids of Chaun tectonic zone and Taigonos Peninsula, NE Asia.

\begin{tabular}{|c|c|c|c|c|c|c|c|c|c|c|c|c|c|c|c|c|c|}
\hline & 1 & 2 & 3 & 4 & 5 & 6 & 7 & 8 & 9 & 10 & 11 & 12 & 13 & 14 & 15 & 16 & 17 \\
\hline & Tan & Tan & Tan & Tan & Tan & Tan & Tan & Tan & Peek & Peek & Mol & Mol & Mol & Mol & Mol & Mol & Mol \\
\hline No. sample & $2458 \mathrm{~b} / 02$ & $2458 \mathrm{~b} / 02$ & $2458 \mathrm{~b} / 02$ & Uglla/02 & Ugl1a/02 & Ugl1a/02 & Ugl1a/02 & Uglla/02 & $8 \mathrm{a}$ & $8 \mathrm{a}$ & $\mathrm{m} 1$ & $\mathrm{~m} 1$ & $\mathrm{~m} 2$ & $\mathrm{~m} 2$ & M1-11 & Ml-11 & Ml-11 \\
\hline $\mathrm{SiO}_{2}$ & 48.59 & 48.89 & 53.54 & 46.19 & 46.59 & 46.85 & 45.94 & 46.29 & 54.58 & 50.74 & 50.86 & 52.91 & 48.11 & 49.44 & 49.19 & 49.83 & 52.26 \\
\hline $\mathrm{TiO}_{2}$ & 1.17 & 1.56 & 0.16 & 1.61 & 1.25 & 1.03 & 1.18 & 1.30 & 0.13 & 0.48 & 0.79 & 0.29 & 0.94 & 0.64 & 1.27 & 0.76 & 0.38 \\
\hline $\mathrm{Al}_{2} \mathrm{O}_{3}$ & 5.60 & 6.15 & 2.69 & 6.70 & 6.12 & 5.38 & 6.58 & 6.32 & 1.10 & 3.88 & 4.29 & 3.22 & 5.90 & 5.20 & 6.22 & 5.08 & 3.52 \\
\hline $\mathrm{FeO}$ & 17.36 & 15.39 & 14.57 & 21.16 & 21.45 & 22.54 & 22.29 & 21.80 & 16.33 & 19.33 & 17.39 & 16.40 & 19.94 & 18.97 & 15.24 & 17.82 & 16.51 \\
\hline $\mathrm{MnO}$ & 1.05 & 0.50 & 1.19 & 0.93 & 1.25 & 1.09 & 1.05 & 1.04 & 0.65 & 0.64 & 0.58 & 0.67 & 0.52 & 0.78 & 0.53 & 0.65 & 0.49 \\
\hline $\mathrm{MgO}$ & 12.46 & 13.91 & 14.78 & 9.64 & 9.32 & 9.30 & 9.05 & 9.13 & 14.56 & 11.68 & 12.99 & 14.08 & 10.51 & 11.14 & 13.14 & 12.43 & 13.37 \\
\hline $\mathrm{CaO}$ & 11.33 & 11.34 & 12.18 & 11.19 & 11.04 & 11.00 & 11.28 & 11.30 & 11.52 & 11.38 & 11.31 & 11.35 & 11.41 & 11.53 & 11.83 & 11.55 & 12.38 \\
\hline $\mathrm{Na}_{2} \mathrm{O}$ & 1.74 & 1.29 & 0.44 & 1.65 & 1.90 & 1.68 & 1.60 & 1.53 & 0.57 & 1.12 & 0.89 & 0.53 & 1.22 & 1.34 & 1.25 & 1.21 & 0.55 \\
\hline $\mathrm{K}_{2} \mathrm{O}$ & 0.51 & 0.48 & 0.17 & 0.74 & 0.78 & 0.83 & 0.86 & 0.85 & 0.07 & 0.30 & 0.49 & 0.32 & 0.67 & 0.57 & 0.63 & 0.54 & 0.26 \\
\hline Total & 99.95 & 99.60 & 99.75 & 99.98 & 99.92 & 99.81 & 99.91 & 99.74 & 99.51 & 99.55 & 99.59 & 99.77 & 99.22 & 99.61 & 99.30 & 99.87 & 99.72 \\
\hline \multicolumn{18}{|l|}{ f.u. } \\
\hline $\mathrm{Si}$ & 7.01 & 6.95 & 7.55 & 6.81 & 6.91 & 6.95 & 6.82 & 6.88 & 7.71 & 7.34 & 7.27 & 7.45 & 7.06 & 7.20 & 7.08 & 7.16 & 7.47 \\
\hline $\mathrm{Ti}(\mathrm{VI})$ & 0.09 & 0.15 & 0.02 & 0.15 & 0.12 & 0.01 & 0.10 & 0.13 & 0.00 & 0.05 & 0.07 & 0.02 & 0.10 & 0.07 & 0.14 & 0.08 & 0.04 \\
\hline $\mathrm{Ti}(\mathrm{IV})$ & 0.04 & 0.02 & 0.00 & 0.03 & 0.02 & 0.11 & 0.03 & 0.01 & 0.10 & 0.00 & 0.01 & 0.01 & 0.00 & 0.00 & 0.00 & 0.00 & 0.00 \\
\hline $\mathrm{Al}(\mathrm{VI})$ & 0.00 & 0.00 & 0.00 & 0.00 & 0.00 & 0.00 & 0.00 & 0.00 & 0.00 & 0.00 & 0.00 & 0.00 & 0.08 & 0.10 & 0.13 & 0.02 & 0.06 \\
\hline $\mathrm{Al}(\mathrm{IV})$ & 0.95 & 1.03 & 0.45 & 1.16 & 1.07 & 0.94 & 1.15 & 1.11 & 0.18 & 0.66 & 0.72 & 0.53 & 0.94 & 0.80 & 0.92 & 0.84 & 0.53 \\
\hline $\mathrm{Fe}^{3+}(\mathrm{VI})$ & 1.05 & 0.83 & 1.39 & 0.93 & 1.09 & 0.98 & 0.99 & 1.07 & 1.71 & 1.24 & 1.06 & 1.07 & 1.04 & 1.19 & 1.06 & 1.13 & 1.40 \\
\hline $\mathrm{Fe}^{3+}(\mathrm{IV})$ & 0.00 & 0.00 & 0.00 & 0.00 & 0.00 & 0.00 & 0.00 & 0.00 & 0.09 & 0.00 & 0.00 & 0.00 & 0.00 & 0.00 & 0.00 & 0.00 & 0.00 \\
\hline $\mathrm{Fe}^{2+}$ & 1.03 & 0.99 & 0.33 & 1.67 & 1.56 & 1.81 & 1.76 & 1.63 & 0.12 & 1.09 & 1.01 & 0.85 & 1.40 & 1.11 & 0.77 & 1.00 & 0.57 \\
\hline $\mathrm{Mn}$ & 0.13 & 0.06 & 0.14 & 0.12 & 0.16 & 0.14 & 0.13 & 0.13 & 0.08 & 0.08 & 0.07 & 0.08 & 0.06 & 0.10 & 0.06 & 0.08 & 0.06 \\
\hline $\mathrm{Mg}$ & 2.70 & 2.97 & 3.13 & 2.13 & 2.07 & 2.07 & 2.02 & 2.04 & 3.09 & 2.54 & 2.78 & 2.98 & 2.31 & 2.43 & 2.84 & 2.68 & 2.87 \\
\hline $\mathrm{Ca}$ & 1.75 & 1.73 & 1.84 & 1.77 & 1.75 & 1.75 & 1.79 & 1.80 & 1.74 & 1.76 & 1.73 & 1.71 & 1.79 & 1.80 & 1.82 & 1.78 & 1.90 \\
\hline $\mathrm{Na}$ & 0.49 & 0.35 & 0.12 & 0.47 & 0.55 & 0.48 & 0.46 & 0.44 & 0.16 & 0.31 & 0.25 & 0.14 & 0.35 & 0.38 & 0.35 & 0.34 & 0.15 \\
\hline K & 0.09 & 0.09 & 0.03 & 0.14 & 0.15 & 0.16 & 0.16 & 0.16 & 0.01 & 0.06 & 0.09 & 0.06 & 0.13 & 0.11 & 0.12 & 0.10 & 0.05 \\
\hline \multirow[t]{3}{*}{ Mg\# } & 0.56 & 0.62 & 0.65 & 0.45 & 0.44 & 0.43 & 0.42 & 0.43 & 0.62 & 0.52 & 0.57 & 0.61 & 0.49 & 0.51 & 0.61 & 0.56 & 0.59 \\
\hline & 18 & 19 & 20 & 21 & 22 & 23 & 24 & 25 & 26 & 27 & 28 & 29 & 30 & 31 & 32 & 33 & 34 \\
\hline & Mol & Mol & Tels & Tels & Teln & Teln & Teln & Teln & Teln & Teln & Teln & Teln & Teln & Teln & Teln & ET & ET \\
\hline No.sample & $\begin{array}{l}\text { Ml- } \\
2224 / 2\end{array}$ & $\begin{array}{l}\text { M1- } \\
2224 / 2\end{array}$ & 7797-I & $3426 b$ & $6621 u$ & $6621 u$ & $6621 u$ & $6621 u$ & $6621 u$ & $6621 u$ & $6622 u$ & $6623 u$ & $6624 n$ & $6624 n$ & $6624 n$ & $223 / 2$ & $223 / 2$ \\
\hline $\mathrm{SiO}_{2}$ & 47.54 & 47.97 & 45.16 & 44.72 & 43.34 & 42.58 & 43.91 & 43.22 & 42.99 & 45.29 & 43.89 & 42.99 & 44.12 & 42.50 & 42.36 & 49.32 & 52.09 \\
\hline $\mathrm{TiO}_{2}$ & 0.87 & 1.03 & 0.00 & 1.14 & 1.89 & 2.14 & 1.58 & 1.77 & 1.76 & 1.25 & 1.83 & 1.63 & 1.77 & 1.82 & 1.65 & 1.24 & 0.56 \\
\hline $\mathrm{Al}_{2} \mathrm{O}_{3}$ & 6.04 & 5.78 & 7.60 & 8.10 & 7.60 & 7.64 & 7.56 & 7.79 & 7.85 & 7.06 & 7.27 & 7.81 & 7.53 & 8.06 & 7.74 & 6.17 & 4.42 \\
\hline $\mathrm{FeO}$ & 23.14 & 22.68 & 25.98 & 24.17 & 27.12 & 27.00 & 27.16 & 27.04 & 27.56 & 26.31 & 26.96 & 25.81 & 27.91 & 28.42 & 28.18 & 14.82 & 13.08 \\
\hline $\mathrm{MnO}$ & 0.88 & 1.00 & 0.94 & 1.18 & 0.56 & 0.31 & 0.47 & 0.53 & 0.38 & 0.65 & 0.44 & 0.41 & 0.65 & 0.44 & 0.58 & 0.32 & 0.52 \\
\hline $\mathrm{MgO}$ & 8.53 & 8.59 & 6.87 & 7.67 & 4.90 & 5.13 & 4.83 & 4.75 & 4.43 & 5.00 & 4.98 & 5.88 & 3.85 & 3.77 & 3.88 & 14.02 & 15.56 \\
\hline $\mathrm{CaO}$ & 10.57 & 10.71 & 11.40 & 10.39 & 10.77 & 10.79 & 10.93 & 11.06 & 11.01 & 11.18 & 10.75 & 10.82 & 10.77 & 10.44 & 10.95 & 11.84 & 12.15 \\
\hline $\mathrm{Na}_{2} \mathrm{O}$ & 1.74 & 1.52 & 0.84 & 1.78 & 1.98 & 2.70 & 2.00 & 1.94 & 2.12 & 1.51 & 2.28 & 2.77 & 1.57 & 2.50 & 2.64 & 1.37 & 1.03 \\
\hline $\mathrm{K}_{2} \mathrm{O}$ & 0.64 & 0.69 & 0.69 & 0.65 & 1.17 & 1.25 & 1.05 & 1.33 & 1.29 & 1.22 & 0.99 & 1.27 & 1.23 & 1.40 & 1.28 & 0.45 & 0.46 \\
\hline Total & 99.95 & 99.97 & 99.48 & 99.80 & 99.33 & 99.54 & 99.49 & 99.43 & 99.39 & 99.47 & 99.39 & 99.39 & 99.40 & 99.35 & 99.26 & 99.68 & 99.94 \\
\hline \multicolumn{18}{|l|}{ f.u. } \\
\hline $\mathrm{Si}$ & 7.01 & 7.07 & 6.76 & 6.63 & 6.70 & 6.62 & 6.77 & 6.70 & 6.69 & 6.97 & 6.78 & 6.65 & 6.84 & 6.65 & 6.68 & 7.03 & 7.33 \\
\hline $\operatorname{Ti}(V I)$ & 0.10 & 0.11 & 0.00 & 0.13 & 0.22 & 0.25 & 0.18 & 0.21 & 0.21 & 0.14 & 0.21 & 0.19 & 0.21 & 0.21 & 0.20 & 0.13 & 0.06 \\
\hline Ti(IV) & 0.00 & 0.00 & 0.00 & 0.00 & 0.00 & 0.00 & 0.00 & 0.00 & 0.00 & 0.00 & 0.00 & 0.00 & 0.00 & 0.00 & 0.00 & 0.00 & 0.00 \\
\hline $\mathrm{Al}(\mathrm{VI})$ & 0.06 & 0.08 & 0.10 & 0.04 & 0.08 & 0.02 & 0.15 & 0.12 & 0.13 & 0.24 & 0.10 & 0.07 & 0.21 & 0.14 & 0.11 & 0.07 & 0.06 \\
\hline $\mathrm{Al}(\mathrm{IV})$ & 0.99 & 0.93 & 1.24 & 1.37 & 1.30 & 1.38 & 1.23 & 1.30 & 1.31 & 1.03 & 1.22 & 1.35 & 1.16 & 1.35 & 1.32 & 0.97 & 0.67 \\
\hline $\mathrm{Fe}^{3+}(\mathrm{VI})$ & 0.91 & 0.94 & 0.69 & 0.52 & 1.01 & 1.26 & 1.05 & 1.10 & 1.13 & 1.10 & 1.12 & 1.24 & 0.92 & 1.05 & 1.33 & 1.04 & 1.30 \\
\hline $\mathrm{Fe}^{3+}(\mathrm{IV})$ & 0.00 & 0.00 & 0.00 & 0.00 & 0.00 & 0.00 & 0.00 & 0.00 & 0.00 & 0.00 & 0.00 & 0.00 & 0.00 & 0.00 & 0.00 & 0.00 & 0.00 \\
\hline $\mathrm{Fe}^{2+}$ & 1.93 & 1.84 & 2.55 & 2.46 & 2.48 & 2.24 & 2.45 & 2.39 & 2.45 & 2.28 & 2.36 & 2.08 & 2.69 & 2.65 & 2.38 & 0.72 & 0.24 \\
\hline $\mathrm{Mn}$ & 0.11 & 0.12 & 0.12 & 0.15 & 0.07 & 0.04 & 0.06 & 0.07 & 0.05 & 0.08 & 0.06 & 0.05 & 0.09 & 0.06 & 0.08 & 0.04 & 0.06 \\
\hline $\mathrm{Mg}$ & 1.89 & 1.90 & 1.54 & 1.70 & 1.14 & 1.20 & 1.12 & 1.11 & 1.03 & 1.15 & 1.15 & 1.36 & 0.89 & 0.89 & 0.92 & 3.00 & 3.28 \\
\hline $\mathrm{Ca}$ & 1.67 & 1.69 & 1.83 & 1.65 & 1.78 & 1.80 & 1.81 & 1.84 & 1.84 & 1.84 & 1.78 & 1.79 & 1.79 & 1.75 & 1.85 & 1.81 & 1.83 \\
\hline $\mathrm{Na}$ & 0.50 & 0.43 & 0.24 & 0.51 & 0.59 & 0.81 & 0.60 & 0.58 & 0.64 & 0.45 & 0.68 & 0.83 & 0.47 & 0.76 & 0.81 & 0.38 & 0.28 \\
\hline $\mathrm{K}$ & 0.12 & 0.13 & 0.13 & 0.12 & 0.23 & 0.25 & 0.21 & 0.26 & 0.26 & 0.24 & 0.20 & 0.25 & 0.24 & 0.28 & 0.26 & 0.08 & 0.08 \\
\hline \multirow[t]{3}{*}{ Mg\# } & 0.40 & 0.41 & 0.32 & 0.36 & 0.25 & 0.25 & 0.24 & 0.24 & 0.22 & 0.25 & 0.25 & 0.29 & 0.20 & 0.19 & 0.20 & 0.63 & 0.68 \\
\hline & 35 & 36 & 37 & 38 & 39 & 40 & 41 & & & & & & & & & & \\
\hline & ET & ET & ET & $\mathrm{PT}$ & PT & PT & $\mathrm{PT}$ & & & & & & & & & & \\
\hline No. sample & $223 / 2$ & $223 / 2$ & $223 / 2$ & 208 & 208 & 208 & $210 / 1$ & & & & & & & & & & \\
\hline $\mathrm{SiO}_{2}$ & 48.83 & 50.13 & 52.21 & 44.40 & 49.07 & 48.45 & 49.93 & & & & & & & & & & \\
\hline $\mathrm{TiO}_{2}$ & 1.15 & 1.45 & 0.68 & 1.78 & 0.36 & 0.60 & 1.04 & & & & & & & & & & \\
\hline $\mathrm{Al}_{2} \mathrm{O}_{3}$ & 6.76 & 6.15 & 4.06 & 8.32 & 3.72 & 4.65 & 6.95 & & & & & & & & & & \\
\hline $\mathrm{FeO}$ & 14.73 & 12.25 & 12.78 & 24.63 & 22.00 & 23.62 & 16.70 & & & & & & & & & & \\
\hline $\mathrm{MnO}$ & 0.45 & 0.34 & 0.43 & 0.47 & 0.58 & 0.62 & 0.20 & & & & & & & & & & \\
\hline $\mathrm{MgO}$ & 14.01 & 15.74 & 16.25 & 6.99 & 9.29 & 8.40 & 13.12 & & & & & & & & & & \\
\hline $\mathrm{CaO}$ & 12.09 & 11.71 & 12.28 & 9.92 & 10.64 & 9.92 & 11.62 & & & & & & & & & & \\
\hline $\mathrm{Na}_{2} \mathrm{O}$ & 1.20 & 1.61 & 0.75 & 1.94 & 0.64 & 0.78 & 0.72 & & & & & & & & & & \\
\hline $\mathrm{K}_{2} \mathrm{O}$ & 0.48 & 0.41 & 0.37 & 0.75 & 0.21 & 0.34 & 0.32 & & & & & & & & & & \\
\hline Total & 99.86 & 99.92 & 99.88 & 99.28 & 96.55 & 97.38 & 100.6 & & & & & & & & & & \\
\hline
\end{tabular}


Table 3. Continued.

\begin{tabular}{|c|c|c|c|c|c|c|c|}
\hline & 35 & 36 & 37 & 38 & 39 & 40 & 41 \\
\hline & ET & ET & ET & PT & PT & PT & PT \\
\hline No. sample & $223 / 2$ & $223 / 2$ & $223 / 2$ & 208 & 208 & 208 & $210 / 1$ \\
\hline \multicolumn{8}{|l|}{ f.u. } \\
\hline $\mathrm{Si}$ & 6.95 & 7.04 & 7.31 & 6.64 & 7.38 & 7.22 & 7.01 \\
\hline $\mathrm{Ti}(\mathrm{VI})$ & 0.12 & 0.15 & 0.05 & 0.20 & 0.04 & 0.07 & 0.11 \\
\hline $\mathrm{Ti}(\mathrm{IV})$ & 0.00 & 0.00 & 0.02 & 0.00 & 0.00 & 0.00 & 0.00 \\
\hline $\mathrm{Al}(\mathrm{VI})$ & 0.08 & 0.06 & 0.00 & 0.10 & 0.03 & 0.04 & 0.15 \\
\hline $\mathrm{Al}(\mathrm{IV})$ & 1.05 & 0.96 & 0.67 & 1.36 & 0.62 & 0.78 & 0.99 \\
\hline $\mathrm{Fe}^{3+}(\mathrm{VI})$ & 0.97 & 1.02 & 1.24 & 0.42 & 1.00 & 0.64 & 0.60 \\
\hline $\mathrm{Fe}^{3+}(\mathrm{IV})$ & 0.00 & 0.00 & 0.00 & 0.00 & 0.00 & 0.00 & 0.00 \\
\hline $\mathrm{Fe}^{2+}$ & 0.78 & 0.42 & 0.25 & 2.65 & 1.76 & 2.29 & 1.35 \\
\hline $\mathrm{Mn}$ & 0.05 & 0.04 & 0.05 & 0.06 & 0.07 & 0.08 & 0.02 \\
\hline $\mathrm{Mg}$ & 2.99 & 3.32 & 3.41 & 1.57 & 2.09 & 1.88 & 2.76 \\
\hline $\mathrm{Ca}$ & 1.84 & 1.76 & 1.84 & 1.59 & 1.71 & 1.58 & 1.75 \\
\hline $\mathrm{Na}$ & 0.33 & 0.44 & 0.20 & 0.56 & 0.19 & 0.23 & 0.20 \\
\hline K & 0.09 & 0.07 & 0.07 & 0.14 & 0.04 & 0.06 & 0.06 \\
\hline Mg\# & 0.63 & 0.70 & 0.70 & 0.34 & 0.53 & 0.39 & 0.59 \\
\hline
\end{tabular}

1-8 - Tanyurer batholith; 9, 10 - Peekiney pluton; 11-19 Moltykan batholith; 20-32 - Telekay batholith (20, 21 - southern part, 22-32 - northern part, microgranular enclaves); 33-37 - Eastern Taigonos batholith; 38-41 - Prybrezhny Taigonos pluton. Analyses are obtained at Petrology Department of Moscow State University (electron microscope CAMSCAN-4DV with Link AN 10000 detector, analysts E. V. Guseva and N. N. Korotaeva).

Analytical error is 0.1 to $0.5 \%$. Mineral formulae were calculated on the basis of 13 cations in (IV) and (VI) coordination.

\subsection{Titano-magnetite}

Ti-magnetite is widespread in the granitoids of the Eastern Taigonos and Tanyurer batholiths, where it takes $2-4 \%$ of the total rock volume. In other plutons considered it is present in minor amounts, hundreds to thousands ppm. The microprobe study has revealed virtually ubiquitous occurrence of Ti-magnetite exsolution structures with thin (up to a few microns) lamellae of ilmenite. Average compositions of the grains determined with an unfocused beam (Table 5) correspond to Ti-magnetites with the ulvöspinel content ranging from $1 \%$ to $1.7 \%$ (as in the Eastern Taigonos batholith) and to $3.5 \%$ (as in the Tanyurer pluton).

\subsection{Ilmentite}

Ilmenite has been identified in all the rocks studied. Its abundances, however, are persistently low, less than $1 \%$. Nonetheless, in the granitoids of the Chaun zone, it is the main oxide phase. No evidence of exsolution has been detected in the ilmenites, except for the rocks of the Eastern Taigonos batholith. The ilmenites of this particular pluton stand out from the rest due to their high content of the hematitic component (24-26\%, when recalculated to the bulk composition of a grain), which was the likely cause of their posmagmatic breakdown. The lowest content of hematite, $1-3.5 \%$, is a distinguishing feature of the ilmenites from the

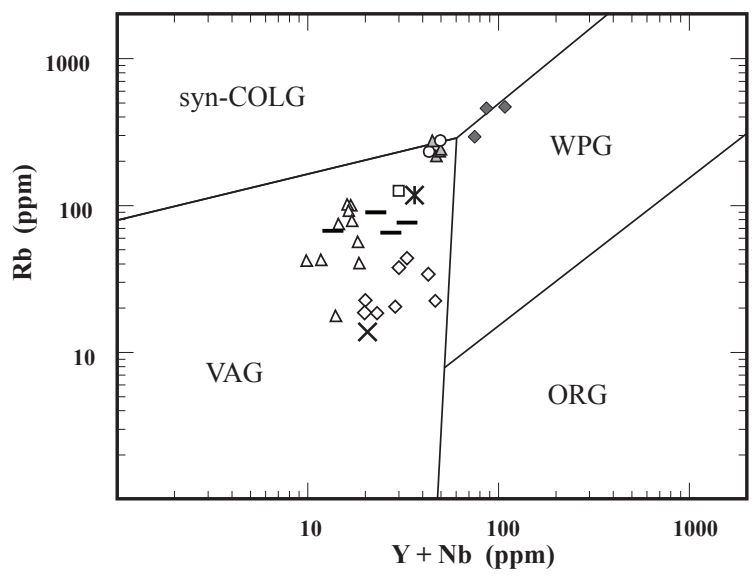

Fig. 7. Discrimination diagram for Cretaceous granitoids of NE Asia: Rb vs. Y+Nb (Pearce et al., 1984).

Compositional fields of granitic rocks: VAG - volcanic arc granites, syn-COLG - syncollisional granites, WPG - within-plate granites, $\mathrm{ORG}$ - ocean ridge granites. Symbols as in Fig. 6.

Peekiney and Moltykan plutons and the northern part of the Telekay pluton. The content of the pyrophanite $\mathrm{MnTiO}_{3}$ component in the ilmenites from the Tanyurer intrusion is on average ca. $15 \%$; in the Eastern Taigonos batholith, $5 \%$; and in the rest of the plutons, $7-12 \%$. In some of the ilmenite grains the content of manganese increases from core to rim, indicating preservation of the magmatic zoning.

On the scale of homogeneous exposures at least tens of meters across, compositional variations of the minerals are insignificant, usually within the analytical error. The only exception is plagioclase, whose outer zones may differ from the inner ones by several tens of percent of the anorthite component (Fig. 10). On the scale of whole plutons, compositions of biotite and amphibole are also more or less uniform (Figs. 8 and 9), and thus may be used as a discriminating parameter. The relatively wide variations of $\mathrm{Mg \#}$ in the mafic silicates of some plutons (Moltykan and Tanyurer batholiths, Prybrezhny Taigonos belt) could be caused by the multipulse formation of these plutons. Systematic differences between minerals which compose granitoids of different geodynamic settings are not clear. We can only note a somewhat higher average $\mathrm{Mg} \#$ of mafic silicates from granites of subductional settings (Tanyurer and Taigonos), in comparison with the post-collisional granites (Chaun zone) (Figs. 8 and 9). The Mg\# in biotite and amphibole positively correlates with the modal abundance of Ti-magnetite - a usual dependence in granitoids crystallized under various redox conditions (e.g., Czamanske et al., 1981).

In comparing compositions of the minerals and rocks, note the positive correlation between the $\mathrm{Mg} \#$ of biotite and amphibole and that of bulk rock samples (Fig. 11a, b). The link between the $\mathrm{Fe} / \mathrm{Mg}$ ratio of the mafic minerals and the silica content of the rocks is also evident, albeit less clear: the data points corresponding to granitoids of the magnetite series 
Table 4. Biotite composition from Cretaceous granitoids of Chaun tectonic zone and Taigonos Peninsula, NE Asia.

\begin{tabular}{|c|c|c|c|c|c|c|c|c|c|c|c|c|c|c|c|c|c|}
\hline №. П/П & $\begin{array}{l}1 \\
\operatorname{Tan}\end{array}$ & $\begin{array}{l}2 \\
\operatorname{Tan}\end{array}$ & $\begin{array}{l}3 \\
\operatorname{Tan}\end{array}$ & $\begin{array}{l}4 \\
\operatorname{Tan}\end{array}$ & $\begin{array}{l}5 \\
\operatorname{Tan}\end{array}$ & $\begin{array}{l}6 \\
\text { Tan }\end{array}$ & $\begin{array}{l}7 \\
\text { Tan }\end{array}$ & $\begin{array}{l}8 \\
\text { Peek }\end{array}$ & $\begin{array}{l}9 \\
\text { Peek }\end{array}$ & $\begin{array}{l}10 \\
\text { Peek }\end{array}$ & $\begin{array}{l}11 \\
\text { Peek }\end{array}$ & $\begin{array}{l}12 \\
\text { Peek }\end{array}$ & $\begin{array}{l}13 \\
\text { Peek }\end{array}$ & $\begin{array}{l}14 \\
\text { Peek }\end{array}$ & $\begin{array}{l}15 \\
\text { Peek }\end{array}$ & $\begin{array}{l}16 \\
\text { Peek }\end{array}$ & $\begin{array}{l}17 \\
\text { Peek }\end{array}$ \\
\hline No. sample & $2458 \mathrm{~b} / 02$ & $2458 \mathrm{~b} / 02$ & $2458 \mathrm{~b} / 02$ & Ug11a/02 & Ugl1 a/02 & $\mathrm{Ug} 11 \mathrm{a} / 02$ & Ug11a/02 & $8 \mathrm{a}$ & $8 \mathrm{a}$ & $8 \mathrm{a}$ & $8 \mathrm{a}$ & $8 \mathrm{a}$ & $8 \mathrm{a}$ & $7 / 5$ & $7 / 5$ & $7 / 5$ & $7 / 5$ \\
\hline $\mathrm{SiO}_{2}$ & 37.88 & 37.92 & 37.83 & 37.16 & 38.52 & 37.24 & 37.03 & 36.66 & 35.24 & 36.68 & 36.35 & 36.35 & 36.90 & 35.64 & 36.20 & 36.12 & 36.31 \\
\hline $\mathrm{TiO}_{2}$ & 4.88 & 5.10 & 4.94 & 4.56 & 3.78 & 4.98 & 4.45 & 4.29 & 4.65 & 3.62 & 4.40 & 4.63 & 4.29 & 4.92 & 4.64 & 4.53 & 4.20 \\
\hline $\mathrm{Al}_{2} \mathrm{O}_{3}$ & 13.62 & 13.31 & 13.45 & 12.84 & 13.31 & 12.92 & 12.99 & 13.07 & 12.37 & 13.10 & 13.16 & 13.32 & 13.17 & 13.18 & 12.91 & 13.20 & 12.83 \\
\hline $\mathrm{FeO}$ & 21.96 & 21.84 & 22.21 & 25.24 & 24.57 & 25.62 & 25.73 & 22.31 & 21.02 & 22.82 & 22.72 & 22.46 & 22.05 & 22.91 & 22.59 & 22.64 & 23.16 \\
\hline $\mathrm{MnO}$ & 0.80 & 0.64 & 0.66 & 0.45 & 0.59 & 0.58 & 0.55 & 0.32 & 0.24 & 0.26 & 0.33 & 0.15 & 0.22 & 0.34 & 0.30 & 0.27 & 0.14 \\
\hline $\mathrm{MgO}$ & 11.07 & 11.06 & 10.87 & 9.32 & 9.18 & 8.74 & 9.08 & 9.79 & 9.04 & 10.19 & 9.51 & 9.36 & 9.44 & 9.42 & 9.26 & 9.66 & 9.28 \\
\hline $\mathrm{CaO}$ & 0.00 & 0.30 & 0.00 & 0.18 & 0.00 & 0.18 & 0.26 & 0.22 & 0.13 & 0.00 & 0.00 & 0.29 & 0.09 & 0.27 & 0.20 & 0.12 & 0.00 \\
\hline $\mathrm{Na}_{2} \mathrm{O}$ & 9.43 & 9.63 & 9.71 & 9.70 & 9.57 & 9.52 & 9.53 & 8.92 & 8.69 & 8.83 & 8.88 & 8.78 & 8.92 & 8.91 & 9.14 & 8.96 & 9.01 \\
\hline $\mathrm{K}_{2} \mathrm{O}$ & n.d. & n.d. & n.d. & n.d. & n.d. & n.d. & n.d. & 0.86 & n.d. & n.d. & n.d. & n.d. & n.d. & n.d. & n.d. & n.d. & n.d. \\
\hline $\mathrm{Cl}$ & 0.20 & 0.21 & 0.26 & 0.19 & 0.13 & 0.25 & 0.17 & 0.30 & 0.25 & 0.22 & 0.28 & 0.20 & 0.23 & 0.30 & 0.52 & 0.36 & 0.64 \\
\hline Total & 99.83 & 100.0 & 99.94 & 99.63 & 99.74 & 100.0 & 99.81 & 96.76 & 91.62 & 95.72 & 95.63 & 95.54 & 95.34 & 95.95 & 95.87 & 95.88 & 95.57 \\
\hline a.f.u. & & & & & & & & & & & & & & & & & \\
\hline $\mathrm{Si}$ & 2.85 & 2.86 & 2.86 & 2.86 & 2.94 & 2.86 & 2.84 & 2.89 & 2.92 & 2.87 & 2.87 & 2.88 & 2.92 & 2.82 & 2.88 & 2.85 & 2.89 \\
\hline $\mathrm{Ti}$ & 0.28 & 0.29 & 0.28 & 0.26 & 0.22 & 0.29 & 0.26 & 0.25 & 0.29 & 0.21 & 0.26 & 0.27 & 0.26 & 0.29 & 0.28 & 0.27 & 0.25 \\
\hline $\mathrm{Al}$ & 1.20 & 1.18 & 1.19 & 1.16 & 1.19 & 1.17 & 1.17 & 1.21 & 1.20 & 1.21 & 1.22 & 1.24 & 1.23 & 1.23 & 1.21 & 1.23 & 1.20 \\
\hline $\mathrm{Fe}$ & 1.38 & 1.37 & 1.40 & 1.62 & 1.56 & 1.64 & 1.65 & 1.47 & 1.45 & 1.49 & 1.50 & 1.48 & 1.46 & 1.51 & 1.50 & 1.49 & 1.54 \\
\hline $\mathrm{Mn}$ & 0.05 & 0.04 & 0.04 & 0.03 & 0.04 & 0.04 & 0.04 & 0.02 & 0.02 & 0.02 & 0.02 & 0.01 & 0.01 & 0.02 & 0.02 & 0.02 & 0.01 \\
\hline $\mathrm{Mg}$ & 1.25 & 1.25 & 1.23 & 1.07 & 1.05 & 1.01 & 1.05 & 1.16 & 1.12 & 1.20 & 1.13 & 1.11 & 1.12 & 1.12 & 1.11 & 1.14 & 1.11 \\
\hline $\mathrm{Na}$ & 0.00 & 0.04 & 0.00 & 0.03 & 0.00 & 0.03 & 0.04 & 0.03 & 0.02 & 0.00 & 0.00 & 0.04 & 0.01 & 0.04 & 0.03 & 0.02 & 0.00 \\
\hline $\mathrm{K}$ & 0.90 & 0.93 & 0.94 & 0.95 & 0.93 & 0.93 & 0.93 & 0.90 & 0.92 & 0.88 & 0.90 & 0.89 & 0.90 & 0.90 & 0.93 & 0.90 & 0.92 \\
\hline $\mathrm{F}$ & - & - & - & - & - & - & - & 0.21 & - & - & - & - & - & - & - & - & - \\
\hline $\mathrm{Cl}$ & 0.02 & 0.03 & 0.03 & 0.02 & 0.02 & 0.03 & 0.02 & 0.04 & 0.03 & 0.03 & 0.04 & 0.03 & 0.03 & 0.04 & 0.07 & 0.05 & 0.09 \\
\hline Mg\# & 0.48 & 0.48 & 0.47 & 0.40 & 0.40 & 0.38 & 0.39 & 0.44 & 0.44 & 0.45 & 0.43 & 0.43 & 0.44 & 0.43 & 0.42 & 0.43 & 0.42 \\
\hline $\begin{array}{l}\mathrm{Al} /(\mathrm{Al}+\mathrm{Si}+ \\
\mathrm{Mg}+\mathrm{Fe})\end{array}$ & 0.18 & 0.18 & 0.18 & 0.17 & 0.18 & 0.17 & 0.17 & 0.18 & 0.18 & 0.18 & 0.18 & 0.18 & 0.18 & 0.18 & 0.18 & 0.18 & 0.18 \\
\hline & 18 & 19 & 20 & 21 & 22 & 23 & 24 & 25 & 26 & 27 & 28 & 29 & 30 & 31 & 32 & 33 & 34 \\
\hline & Mol & Mol & Mol & Mol & Mol & Mol & Mol & Mol & Mol & Mol & Mol & $\mathrm{Mol}$ & Mol & Tel & Tel & $\mathrm{Tel}$ & Tel \\
\hline No. sample. & $\mathrm{m} 2 / 1 \mathrm{a}$ & $\mathrm{m} 2 / 1 \mathrm{~b}$ & Ml-11 & Ml-11 & Ml-11 & Ml-11 & Ml-11 & Ml-2224-2 & Ml-2224-2 & Ml-2224-2 & Ml-2224-2 & Ml-2224-2 & Ml-2224-2 & 7797-I & 7797-I & 7797-I & 7797-I \\
\hline $\mathrm{SiO}_{2}$ & 36.80 & 36.20 & 35.99 & 36.74 & 36.83 & 36.89 & 37.19 & 35.32 & 36.18 & 35.36 & 36.83 & 35.86 & 35.74 & 35.45 & 35.00 & 35.07 & 34.66 \\
\hline $\mathrm{TiO}_{2}$ & 4.44 & 4.53 & 4.02 & 4.61 & 3.96 & 3.66 & 3.33 & 4.51 & 3.98 & 4.33 & 4.51 & 4.23 & 3.83 & 3.33 & 3.90 & 3.02 & 3.50 \\
\hline $\mathrm{Al}_{2} \mathrm{O}_{3}$ & 13.05 & 13.34 & 12.97 & 13.29 & 13.54 & 13.67 & 13.65 & 13.64 & 13.05 & 13.45 & 14.01 & 13.37 & 13.43 & 14.19 & 14.11 & 14.37 & 14.64 \\
\hline $\mathrm{FeO}$ & 21.39 & 22.37 & 19.57 & 20.77 & 20.50 & 21.17 & 20.48 & 26.40 & 24.99 & 26.45 & 27.55 & 24.88 & 25.95 & 26.66 & 26.44 & 27.19 & 27.67 \\
\hline $\mathrm{MnO}$ & 0.37 & 0.49 & 0.25 & 0.23 & 0.25 & 0.40 & 0.34 & 0.41 & 0.30 & 0.36 & 0.38 & 0.55 & 0.36 & 0.52 & 0.34 & 0.40 & 0.56 \\
\hline $\mathrm{MgO}$ & 9.96 & 9.52 & 10.14 & 10.61 & 11.25 & 11.04 & 11.67 & 7.65 & 8.47 & 7.95 & 8.28 & 8.21 & 8.18 & 6.30 & 6.66 & 6.58 & 6.42 \\
\hline $\mathrm{CaO}$ & 0.00 & 0.00 & 0.19 & 0.44 & 0.36 & 0.15 & 0.29 & 0.52 & 0.32 & 0.33 & 0.34 & 0.25 & 0.12 & 0.27 & 0.17 & 0.23 & 0.03 \\
\hline $\mathrm{Na}_{2} \mathrm{O}$ & 9.15 & 9.07 & 8.78 & 8.86 & 8.67 & 8.64 & 8.54 & 8.67 & 8.55 & 7.61 & 7.93 & 8.57 & 8.25 & 8.79 & 9.02 & 8.82 & 8.11 \\
\hline $\mathrm{K}_{2} \mathrm{O}$ & n.d. & n.d. & n.d. & 0.55 & n.d. & n.d. & n.d. & 1.44 & n.d. & n.d. & n.d. & n.d. & n.d. & 0.29 & n.d. & n.d. & n.d. \\
\hline $\mathrm{Cl}$ & 0.09 & 0.10 & 0.15 & 0.13 & 0.14 & 0.10 & 0.14 & 0.16 & 0.16 & 0.12 & 0.12 & 0.09 & 0.10 & 0.32 & 0.26 & 0.31 & 0.28 \\
\hline Total & 95.24 & 95.63 & 92.05 & 96.24 & 95.55 & 95.73 & 95.65 & 98.73 & 96.00 & 96.00 & 100.0 & 96.01 & 96.01 & 96.13 & 95.90 & 96.00 & 95.88 \\
\hline a.f.u. & & & & & & & & & & & & & & & & & \\
\hline $\mathrm{Si}$ & 2.91 & 2.86 & 2.93 & 2.88 & 2.87 & 2.86 & 2.87 & 2.79 & 2.87 & 2.79 & 2.79 & 2.84 & 2.82 & 2.86 & 2.82 & 2.82 & 2.77 \\
\hline $\mathrm{Ti}$ & 0.26 & 0.27 & 0.25 & 0.27 & 0.23 & 0.21 & 0.19 & 0.27 & 0.24 & 0.26 & 0.26 & 0.25 & 0.23 & 0.20 & 0.24 & 0.18 & 0.21 \\
\hline $\mathrm{Al}$ & 1.21 & 1.24 & 1.24 & 1.23 & 1.24 & 1.25 & 1.24 & 1.27 & 1.22 & 1.25 & 1.25 & 1.25 & 1.25 & 1.35 & 1.34 & 1.36 & 1.38 \\
\hline $\mathrm{Fe}$ & 1.41 & 1.47 & 1.33 & 1.36 & 1.33 & 1.37 & 1.32 & 1.74 & 1.65 & 1.74 & 1.74 & 1.64 & 1.71 & 1.79 & 1.78 & 1.82 & 1.84 \\
\hline $\mathrm{Mn}$ & 0.03 & 0.03 & 0.02 & 0.02 & 0.02 & 0.03 & 0.02 & 0.03 & 0.02 & 0.02 & 0.02 & 0.04 & 0.02 & 0.04 & 0.02 & 0.03 & 0.04 \\
\hline $\mathrm{Mg}$ & 1.18 & 1.13 & 1.24 & 1.25 & 1.31 & 1.28 & 1.35 & 0.91 & 1.01 & 0.94 & 0.94 & 0.98 & 0.97 & 0.76 & 0.81 & 0.79 & 0.77 \\
\hline $\mathrm{Na}$ & 0.00 & 0.00 & 0.03 & 0.07 & 0.05 & 0.02 & 0.04 & 0.08 & 0.05 & 0.05 & 0.05 & 0.04 & 0.02 & 0.04 & 0.03 & 0.04 & 0.00 \\
\hline K & 0.92 & 0.91 & 0.91 & 0.89 & 0.86 & 0.86 & 0.84 & 0.87 & 0.87 & 0.77 & 0.77 & 0.87 & 0.83 & 0.91 & 0.93 & 0.91 & 0.83 \\
\hline $\mathrm{F}$ & - & - & - & 0.14 & - & - & - & 0.36 & - & - & - & - & - & 0.07 & - & - & - \\
\hline $\mathrm{Cl}$ & 0.01 & 0.01 & 0.02 & 0.02 & 0.02 & 0.01 & 0.02 & 0.02 & 0.02 & 0.02 & 0.02 & 0.01 & 0.01 & 0.04 & 0.04 & 0.04 & 0.04 \\
\hline Mg\# & 0.46 & 0.43 & 0.48 & 0.48 & 0.50 & 0.48 & 0.51 & 0.36 & 0.38 & 0.35 & 0.35 & 0.70 & 0.36 & 0.30 & 0.31 & 0.30 & 29.00 \\
\hline $\begin{array}{l}\mathrm{Al} /(\mathrm{Al}+\mathrm{Si}+ \\
\mathrm{Mg}+\mathrm{Fe})\end{array}$ & 0.18 & 0.19 & 0.18 & 0.18 & 0.18 & 0.18 & 0.18 & 0.19 & 0.18 & 0.19 & 0.19 & 0.19 & 0.18 & 0.20 & 0.20 & 0.20 & 0.20 \\
\hline & 35 & 36 & 37 & 38 & 39 & 40 & 41 & 42 & 43 & 44 & 45 & 46 & 47 & 48 & 49 & 50 & 51 \\
\hline & Tel & Tel & Tel & $\mathrm{Tel}$ & Tel & Tel & Tel & Tel & Tel & Tel & Tel & Tel & Tel & Tel & Tel & Tel & Tel \\
\hline No. sample & 7797-I & 7797-I & 7797-I & $3426 \mathrm{~b}$ & $6621 d$ & $6621 d$ & $6621 d$ & $6621 \mathrm{~d}$ & $6621 \mathrm{~g}$ & $6621 \mathrm{~g}$ & $6621 \mathrm{~g}$ & $6621 \mathrm{~g}$ & $6621 n$ & $662 \ln$ & $6621 u$ & $6621 u$ & $6621 u$ \\
\hline $\mathrm{SiO}_{2}$ & 34.67 & 35.09 & 34.84 & 34.78 & 34.40 & 36.83 & 35.52 & 35.11 & 35.33 & 35.17 & 35.68 & 34.43 & 36.17 & 35.48 & 35.73 & 35.21 & 35.58 \\
\hline $\mathrm{TiO}_{2}$ & 4.28 & 3.90 & 3.55 & 4.27 & 4.52 & 3.44 & 4.30 & 4.39 & 3.71 & 3.95 & 3.54 & 3.87 & 4.30 & 3.92 & 4.57 & 4.68 & 4.23 \\
\hline $\mathrm{Al}_{2} \mathrm{O}_{3}$ & 14.06 & 14.28 & 14.52 & 13.97 & 12.50 & 11.98 & 11.83 & 11.83 & 11.78 & 11.72 & 12.12 & 12.64 & 11.98 & 11.88 & 11.42 & 12.02 & 11.96 \\
\hline $\mathrm{FeO}$ & 27.23 & 26.69 & 26.79 & 26.98 & 29.44 & 27.74 & 28.55 & 28.84 & 30.05 & 30.22 & 29.88 & 30.90 & 28.65 & 29.31 & 28.48 & 28.17 & 27.98 \\
\hline $\mathrm{MnO}$ & 0.48 & 0.40 & 0.36 & 0.39 & 0.28 & 0.31 & 0.23 & 0.11 & 0.14 & 0.16 & 0.32 & 0.20 & 0.16 & 0.25 & 0.08 & 0.20 & 0.38 \\
\hline $\mathrm{MgO}$ & 6.06 & 6.39 & 6.49 & 7.52 & 5.07 & 5.92 & 5.07 & 5.26 & 4.80 & 4.24 & 4.71 & 4.51 & 4.62 & 4.95 & 5.29 & 5.20 & 5.48 \\
\hline $\mathrm{CaO}$ & 0.11 & 0.00 & 0.05 & 0.12 & 0.09 & 0.01 & 0.15 & 0.24 & 0.25 & 0.36 & 0.00 & 0.00 & 0.00 & 0.36 & 0.12 & 0.20 & 0.00 \\
\hline $\mathrm{Na}_{2} \mathrm{O}$ & 8.87 & 8.86 & 9.05 & 7.67 & 9.13 & 9.30 & 9.69 & 9.19 & 9.27 & 9.52 & 9.14 & 8.82 & 9.63 & 9.00 & 9.57 & 9.64 & 9.74 \\
\hline $\mathrm{K}_{2} \mathrm{O}$ & n.d. & n.d. & n.d. & n.d. & n.d. & n.d. & n.d. & n.d. & n.d. & n.d. & n.d. & n.d. & n.d. & n.d. & n.d. & n.d. & n.d. \\
\hline $\mathrm{Cl}$ & 0.18 & 0.34 & 0.27 & 0.23 & 0.50 & 0.47 & 0.56 & 0.65 & 0.58 & 0.00 & 0.00 & 0.00 & 0.50 & 0.68 & 0.66 & 0.68 & 0.64 \\
\hline Total & 95.93 & 95.95 & 95.91 & 95.92 & 95.93 & 96.00 & 95.89 & 95.61 & 95.90 & 95.35 & 95.40 & 95.38 & 96.01 & 95.85 & 95.92 & 96.00 & 96.01 \\
\hline a.f.u. & & & & & & & & & & & & & & & & & \\
\hline $\mathrm{Si}$ & 2.80 & 2.82 & 2.80 & 2.75 & 2.84 & 3.01 & 2.95 & 2.91 & 2.93 & 2.94 & 2.94 & 2.84 & 3.00 & 2.94 & 2.97 & 2.92 & 2.94 \\
\hline $\mathrm{Ti}$ & 0.26 & 0.24 & 0.21 & 0.25 & 0.28 & 0.21 & 0.27 & 0.27 & 0.23 & 0.25 & 0.22 & 0.24 & 0.27 & 0.24 & 0.28 & 0.29 & 0.26 \\
\hline $\mathrm{Al}$ & 1.34 & 1.35 & 1.37 & 1.30 & 1.21 & 1.15 & 1.16 & 1.16 & 1.15 & 1.15 & 1.18 & 1.23 & 1.17 & 1.16 & 1.12 & 1.17 & 1.16 \\
\hline $\mathrm{Fe}$ & 1.83 & 1.79 & 1.80 & 1.78 & 2.02 & 1.89 & 1.98 & 1.99 & 2.08 & 2.11 & 2.05 & 2.12 & 1.98 & 2.02 & 1.97 & 1.95 & 1.93 \\
\hline $\mathrm{Mn}$ & 0.03 & 0.03 & 0.02 & 0.03 & 0.02 & 0.02 & 0.02 & 0.01 & 0.01 & 0.01 & 0.02 & 0.01 & 0.01 & 0.02 & 0.01 & 0.01 & 0.03 \\
\hline $\mathrm{Mg}$ & 0.73 & 0.77 & 0.78 & 0.89 & 0.63 & 0.73 & 0.63 & 0.66 & 0.60 & 0.53 & 0.58 & 0.56 & 0.57 & 0.62 & 0.66 & 0.65 & 0.68 \\
\hline $\mathrm{Na}$ & 0.02 & 0.00 & 0.01 & 0.02 & 0.01 & 0.00 & 0.02 & 0.04 & 0.04 & 0.06 & 0.00 & 0.00 & 0.00 & 0.06 & 0.02 & 0.03 & 0.00 \\
\hline K & 0.92 & 0.91 & 0.93 & 0.77 & 0.96 & 0.97 & 1.03 & 0.97 & 0.98 & 1.02 & 0.96 & 0.93 & 1.02 & 0.95 & 1.01 & 1.02 & 1.03 \\
\hline $\mathrm{F}$ & - & - & - & - & - & - & - & - & - & - & - & - & - & - & - & - & - \\
\hline $\mathrm{Cl}$ & 0.02 & 0.05 & 0.04 & 0.03 & 0.07 & 0.06 & 0.08 & 0.09 & 0.08 & 0.00 & 0.00 & 0.00 & 0.07 & 0.10 & 0.09 & 0.10 & 0.09 \\
\hline Mg\# & 0.29 & 0.30 & 0.30 & 0.33 & 24.00 & 0.28 & 0.24 & 0.25 & 0.22 & 0.20 & 0.22 & 0.21 & 0.22 & 0.23 & 0.25 & 0.26 & 0.26 \\
\hline $\mathbf{A} \mathbf{l} /(\mathbf{A l}+\mathbf{S i}+$ & & & & & & & & & & & & & & & & & \\
\hline $\mathrm{Mg}+\mathrm{Fe})$ & 0.20 & 0.20 & 0.20 & 0.19 & 0.18 & 0.17 & 0.17 & 0.17 & 0.17 & 0.17 & 0.17 & 0.18 & 0.17 & 0.17 & 0.17 & 0.18 & 0.17 \\
\hline
\end{tabular}


Table 4. Continued.

\begin{tabular}{|c|c|c|c|c|c|c|c|c|c|c|c|c|c|c|c|c|c|}
\hline & 52 & 53 & 54 & 55 & $\begin{array}{l}56 \\
\text { ET }\end{array}$ & $\begin{array}{l}57 \\
\text { FT }\end{array}$ & 58 & $\begin{array}{l}59 \\
\text { FT }\end{array}$ & $\begin{array}{l}60 \\
\text { PT }\end{array}$ & $\begin{array}{l}61 \\
\text { PT }\end{array}$ & $\begin{array}{l}62 \\
\text { PT }\end{array}$ & $\begin{array}{l}63 \\
\text { PT }\end{array}$ & $\begin{array}{l}64 \\
\text { PT }\end{array}$ & $\begin{array}{l}65 \\
\text { PT }\end{array}$ & $\begin{array}{l}66 \\
\text { PT }\end{array}$ & $\begin{array}{l}67 \\
\text { PT }\end{array}$ & $\begin{array}{l}68 \\
\text { PT }\end{array}$ \\
\hline No. sample & $\begin{array}{l}\text { Tel } \\
6621 u\end{array}$ & $\begin{array}{l}\text { Tel } \\
6621 \mathrm{u}\end{array}$ & $\begin{array}{l}\text { Tel } \\
6621 u\end{array}$ & $\begin{array}{l}\text { Tel } \\
6621 u\end{array}$ & $\begin{array}{l}\text { ET } \\
223 / 2\end{array}$ & $\begin{array}{l}\text { ET } \\
223 / 2\end{array}$ & $\begin{array}{l}\text { ET } \\
223 / 2\end{array}$ & $\begin{array}{l}\text { ET } \\
223 / 2\end{array}$ & $\begin{array}{l}\text { PT } \\
205\end{array}$ & $\begin{array}{l}\text { PT } \\
205\end{array}$ & $\begin{array}{l}\text { PT } \\
205\end{array}$ & $\begin{array}{l}\text { PT } \\
208\end{array}$ & $\begin{array}{l}\text { PT } \\
208\end{array}$ & $\begin{array}{l}\text { PT } \\
208\end{array}$ & $\begin{array}{l}\text { PT } \\
208 / 6\end{array}$ & $\begin{array}{l}\text { PT } \\
208 / 6\end{array}$ & $\begin{array}{l}\text { PT } \\
208 / 6\end{array}$ \\
\hline $\mathrm{SiO}_{2}$ & 35.89 & 35.53 & 36.02 & 35.87 & 38.07 & 38.62 & 38.86 & 38.53 & 36.07 & 36.97 & 35.76 & 35.60 & 35.81 & 36.33 & 37.11 & 36.18 & 36.82 \\
\hline $\mathrm{TiO}_{2}$ & 4.39 & 4.64 & 4.00 & 4.09 & 4.78 & 4.65 & 3.87 & 4.52 & 4.16 & 4.10 & 3.88 & 3.53 & 3.95 & 3.90 & 3.90 & 3.55 & 4.12 \\
\hline $\mathrm{Al}_{2} \mathrm{O}_{3}$ & 12.20 & 12.01 & 11.92 & 11.79 & 13.86 & 14.13 & 14.34 & 14.40 & 15.58 & 15.23 & 14.51 & 14.63 & 14.22 & 14.72 & 14.77 & 14.44 & 14.12 \\
\hline $\mathrm{FeO}$ & 27.33 & 27.94 & 28.51 & 28.52 & 18.69 & 18.27 & 18.77 & 18.90 & 22.73 & 23.60 & 23.99 & 26.76 & 27.09 & 26.41 & 22.97 & 21.76 & 22.28 \\
\hline $\mathrm{MnO}$ & 0.21 & 0.15 & 0.11 & 0.02 & 0.17 & 0.27 & 0.22 & 0.21 & 0.15 & 0.19 & 0.16 & 0.24 & 0.34 & 0.27 & 0.30 & 0.28 & 0.19 \\
\hline $\mathrm{MgO}$ & 5.58 & 5.20 & 5.24 & 5.28 & 13.56 & 13.55 & 13.71 & 13.26 & 8.79 & 8.92 & 8.42 & 7.08 & 6.89 & 6.95 & 8.96 & 8.68 & 8.84 \\
\hline $\mathrm{CaO}$ & 0.00 & 0.00 & 0.00 & 0.10 & 0.92 & 0.55 & 0.40 & 0.27 & 0.28 & 0.20 & 0.24 & 0.21 & 0.12 & 0.14 & 0.14 & 0.29 & 0.18 \\
\hline $\mathrm{Na}_{2} \mathrm{O}$ & 9.77 & 9.82 & 9.60 & 9.86 & 9.53 & 9.68 & 9.37 & 9.62 & 9.04 & 9.40 & 8.87 & 9.35 & 9.18 & 9.80 & 8.06 & 7.20 & 7.11 \\
\hline $\mathrm{K}_{2} \mathrm{O}$ & n.d. & n.d. & n.d. & n.d. & n.d. & n.d. & n.d. & n.d. & n.d. & n.d. & n.d. & 0.04 & 0.21 & n.d. & 0.24 & 0.36 & 0.04 \\
\hline $\mathrm{Cl}$ & 0.56 & 0.61 & 0.56 & 0.49 & 0.11 & 0.09 & 0.09 & 0.05 & 0.15 & 0.15 & 0.15 & 0.13 & 0.18 & 0.17 & 0.19 & 0.26 & 0.26 \\
\hline Total & 95.93 & 95.90 & 95.96 & 96.01 & 99.79 & 99.80 & 99.78 & 99.84 & 96.98 & 98.78 & 96.07 & 97.65 & 98.09 & 98.77 & 96.68 & 93.08 & 93.96 \\
\hline $\begin{array}{l}\text { a.f.u. } \\
\mathrm{Si}\end{array}$ & 2.96 & 2.95 & 2.97 & 2.97 & 2.83 & 2.86 & 2.86 & 2.85 & 2.81 & 2.84 & 2.83 & 2.81 & 2.83 & 2.85 & 2.88 & 2.90 & 2.91 \\
\hline $\mathrm{Ti}$ & 0.27 & 0.29 & 0.25 & 0.25 & 0.27 & 0.26 & 0.21 & 0.25 & 0.24 & 0.24 & 0.23 & 0.21 & 0.23 & 0.23 & 0.23 & 0.21 & 0.24 \\
\hline $\mathrm{Al}$ & 1.18 & 1.17 & 1.16 & 1.15 & 1.21 & 1.23 & 1.24 & 1.25 & 1.43 & 1.38 & 1.35 & 1.36 & 1.32 & 1.36 & 1.35 & 1.36 & 1.31 \\
\hline $\mathrm{Fe}$ & 1.88 & 1.93 & 1.96 & 1.97 & 1.16 & 1.13 & 1.15 & 1.16 & 1.48 & 1.51 & 1.58 & 1.76 & 1.78 & 1.73 & 1.48 & 1.46 & 1.47 \\
\hline $\mathrm{Mn}$ & 0.01 & 0.01 & 0.01 & 0.00 & 0.01 & 0.02 & 0.01 & 0.01 & 0.01 & 0.01 & 0.01 & 0.02 & 0.02 & 0.02 & 0.02 & 0.02 & 0.01 \\
\hline $\mathrm{Mg}$ & 0.69 & 0.65 & 0.65 & 0.66 & 1.51 & 1.51 & 1.52 & 1.47 & 1.03 & 1.03 & 1.00 & 0.84 & 0.82 & 0.82 & 1.04 & 1.04 & 1.05 \\
\hline $\mathrm{Na}$ & 0.00 & 0.00 & 0.00 & 0.02 & 0.13 & 0.08 & 0.06 & 0.04 & 0.04 & 0.03 & 0.04 & 0.03 & 0.02 & 0.02 & 0.02 & 0.05 & 0.03 \\
\hline K & 1.03 & 1.04 & 1.01 & 1.04 & 0.91 & 0.92 & 0.88 & 0.91 & 0.90 & 0.92 & 0.90 & 0.94 & 0.92 & 0.98 & 0.80 & 0.74 & 0.72 \\
\hline $\mathrm{F}$ & - & - & - & - & - & - & - & - & - & - & - & 0.01 & 0.05 & - & 0.06 & 0.09 & 0.01 \\
\hline $\mathrm{Cl}$ & 0.08 & 0.09 & 0.08 & 0.07 & 0.01 & 0.01 & 0.01 & 0.01 & 0.02 & 0.02 & 0.02 & 0.02 & 0.02 & 0.02 & 0.02 & 0.04 & 0.03 \\
\hline Mg\# & 0.27 & 0.25 & 0.25 & 0.25 & 0.57 & 0.57 & 0.57 & 0.56 & 0.41 & 0.40 & 0.39 & 0.32 & 0.31 & 0.32 & 0.41 & 0.42 & 0.42 \\
\hline $\mathbf{A l} /(\mathbf{A l}+$ & & & & & & & & & & & & & & & & & \\
\hline $\mathrm{Si}+\mathrm{Mg}+\mathrm{Fe})$ & 0.18 & 0.17 & 0.17 & 0.17 & 0.18 & 0.18 & 0.18 & 0.19 & 0.21 & 0.20 & 0.20 & 0.20 & 0.20 & 0.20 & 0.20 & 0.20 & 0.19 \\
\hline
\end{tabular}

1-7 - Tanyurer batholith; 8-17 - Peekiney pluton; 18-30 - Moltykan batholith; 31-55 - Telekay batholith (31-38 - southern part, 39-46 - northern part, leucogranites; 47-55 northern part, MME; 56-59 - Eastern-Taigonos batholith; 60-68 - Prybrezhno-Taigonos pluton. Analyses 8, 21, 25 and 31 are obtained at Microanalysis Laboratory, Mineralogy Department, Moscow State University (microscope Camebax SX 50, analyst N. N. Kononkova), analyses 9 and 20, at Institute of Mineralogy, Geochemistry and Crystallochemistry of Rare Elements (Camebax Microbeam, analyst I. M. Kulikova). Other analyses are obtained at Petrology Department, Moscow State University (electronic microscoe CAMSCAN4DV, Link AN 10000, analysts E. V. Guseva and N. N. Korotaeva. Analysis error is 0.1 to $0.5 \%$. Mineral formulae were calculated on the basis of 7 cations in coordination (IV) and (VI).

Table 5. Titanomagnetite and ilmenite composition from Cretaceous granitoids of Chaun tectonic zone and Taigonos Peninsula, NE Asia.

\begin{tabular}{|c|c|c|c|c|c|c|c|c|c|c|c|c|c|c|c|c|c|c|}
\hline & $\begin{array}{l}1 \\
\text { Tan }\end{array}$ & $\begin{array}{l}2 \\
\text { Tan }\end{array}$ & $\begin{array}{l}3 \\
\text { Tan }\end{array}$ & $\begin{array}{l}4 \\
\text { Tan }\end{array}$ & $\begin{array}{l}5 \\
\text { Tan }\end{array}$ & $\begin{array}{l}6 \\
\text { Peek }\end{array}$ & $\begin{array}{l}7 \\
\text { Peek }\end{array}$ & $\begin{array}{l}8 \\
\text { Peek }\end{array}$ & $\begin{array}{l}9 \\
\mathrm{Mol}\end{array}$ & $\begin{array}{l}10 \\
\text { Mol }\end{array}$ & $\begin{array}{l}11 \\
\text { Tel }\end{array}$ & $\begin{array}{l}12 \\
\text { Tel }\end{array}$ & $\begin{array}{l}13 \\
\text { Tel }\end{array}$ & $\begin{array}{l}14 \\
\text { Tel }\end{array}$ & $\begin{array}{l}15 \\
\text { ET }\end{array}$ & $\begin{array}{l}16 \\
\text { ET }\end{array}$ & $\begin{array}{l}17 \\
\text { ET }\end{array}$ & $\begin{array}{l}18 \\
\text { ET }\end{array}$ \\
\hline No. sample & $2458 \mathrm{~b} / 02$ & $2458 \mathrm{~b} / 02$ & $\mathrm{Uglla} / 02$ & $\mathrm{Ugl1a} / 02$ & $\mathrm{Uglla} / 02$ & $8 a$ & $7 / 5$ & $7 / 5$ & Ml-11 & Ml-2224/2 & 7797-I & 7797-I & 7797-I & $6621 u$ & $223 / 2$ & $223 / 2$ & $223 / 2$ & $223 / 2$ \\
\hline $\mathrm{SiO}_{2}$ & 1.29 & 0.30 & 0.51 & 1.74 & 0.11 & n.d. & n.d. & n.d. & n.d. & n.d. & n.d. & n.d. & n.d. & n.d. & 0.49 & 0.49 & 0.99 & 0.45 \\
\hline $\mathrm{TiO}_{2}$ & 0.34 & 1.25 & 0.19 & 47.68 & 49.87 & 50.82 & 50.99 & 50.28 & 52.86 & 50.39 & 50.18 & 50.03 & 49.39 & 51.81 & 0.62 & 0.58 & 39.25 & 39.24 \\
\hline $\mathrm{Al}_{2} \mathrm{O}_{3}$ & 0.60 & 0.25 & 0.27 & 0.23 & 0.00 & 0.00 & 0.00 & 0.00 & 0.00 & 0.00 & 0.00 & 0.03 & 0.00 & 0.24 & 0.32 & 0.32 & 0.18 & 0.05 \\
\hline $\mathrm{FeO}$ & 94.99 & 94.58 & 95.62 & 39.56 & 42.69 & 45.26 & 43.32 & 42.93 & 46.69 & 41.00 & 46.12 & 47.54 & 44.58 & 42.08 & 94.92 & 94.63 & 55.33 & 56.24 \\
\hline $\mathrm{MnO}$ & 0.11 & 0.20 & 0.35 & 6.56 & 6.74 & 2.57 & 4.41 & 4.94 & 3.00 & 7.48 & 5.21 & 5.24 & 5.38 & 5.50 & 0.13 & 0.13 & 1.47 & 2.70 \\
\hline $\mathrm{ZnO}$ & 0.03 & 0.61 & 0.40 & 0.12 & 0.40 & n.d. & n.d. & n.d. & n.d. & n.d. & n.d. & n.d. & n.d. & n.d. & 0.00 & 0.00 & 0.26 & 0.00 \\
\hline $\mathrm{V}_{2} \mathrm{O}_{5}$ & 0.44 & 0.46 & 0.36 & 0.00 & 0.11 & n.d. & n.d. & n.d. & n.d. & n.d. & n.d. & n.d. & n.d. & n.d. & n.d. & 0.38 & n.d. & n.d. \\
\hline Total & 97.79 & 97.64 & 97.71 & 95.34 & 99.80 & 98.65 & 98.72 & 98.15 & 102.55 & 98.87 & 101.51 & 102.85 & 99.35 & 99.63 & 96.48 & 96.54 & 96.47 & 98.86 \\
\hline \multicolumn{19}{|l|}{ f.u. } \\
\hline $\mathrm{Ti}$ & 0.01 & 0.03 & 0.01 & 0.96 & 0.95 & 0.98 & 0.98 & 0.97 & 0.98 & 0.97 & 0.93 & 0.92 & 0.94 & 0.99 & 0.02 & 0.02 & 0.76 & 0.74 \\
\hline $\mathrm{Al}$ & 0.03 & 0.01 & 0.01 & 0.01 & 0.00 & 0.00 & 0.00 & 0.00 & 0.00 & 0.00 & 0.00 & 0.00 & 0.00 & 0.01 & 0.01 & 0.01 & 0.01 & 0.00 \\
\hline $\mathrm{Fe}$ & 2.96 & 2.94 & 2.97 & 0.88 & 0.90 & 0.97 & 0.92 & 0.92 & 0.96 & 0.87 & 0.95 & 0.97 & 0.94 & 0.89 & 2.96 & 2.96 & 1.19 & 1.18 \\
\hline $\mathrm{Mn}$ & 0.00 & 0.01 & 0.01 & 0.15 & 0.14 & 0.06 & 0.10 & 0.11 & 0.06 & 0.16 & 0.11 & 0.11 & 0.12 & 0.12 & 0.00 & 0.00 & 0.03 & 0.06 \\
\hline $\mathrm{Mg}$ & 0.00 & 0.01 & 0.01 & 0.00 & 0.00 & 0.00 & 0.00 & 0.00 & 0.00 & 0.00 & 0.00 & 0.00 & 0.00 & 0.00 & 0.01 & 0.01 & 0.01 & 0.02 \\
\hline \multicolumn{19}{|l|}{$\begin{array}{l}\text { mineral } \\
\text { fraction }\end{array}$} \\
\hline ulvospinel & 0.94 & 3.50 & 0.54 & - & - & - & - & - & - & - & - & - & - & - & 1.73 & 1.63 & - & - \\
\hline hematite & - & - & - & 4.23 & 4.96 & 2.27 & 2.03 & 2.88 & 2.39 & 3.44 & 6.67 & 8.19 & 5.91 & 1.44 & - & - & 23.94 & 26.08 \\
\hline pyrophanite & - & - & - & 14.84 & 14.48 & 5.57 & 9.55 & 10.75 & 6.25 & 16.15 & 10.93 & 10.84 & 11.55 & 11.79 & - & - & 3.21 & 5.72 \\
\hline
\end{tabular}

1-5 - Tanyurer batholith; 6-8 - Peekiney pluton; 9, 10 - Moltykan batholith; 11-14 - Telekay batholith (11-13 - southern part, 14 - northern part, microgranular enclaves, 15-18 Eastern Taigonos batholith.

Analyses 9, 11, 12 are obtained at Microanalysis Laboratory, Mineralogy Department, Moscow State University (microscope Camebax SX 50, analyst N. N. Kononkova), rest analyses, at Petrology Departement, Moscow State University (electronic microscope CAMSCAN-4DV, Link AN 10000, analysts E. V. Guseva, N. N. Korotaeva). Analysis error is 0.1 to $0.5 \%$. 


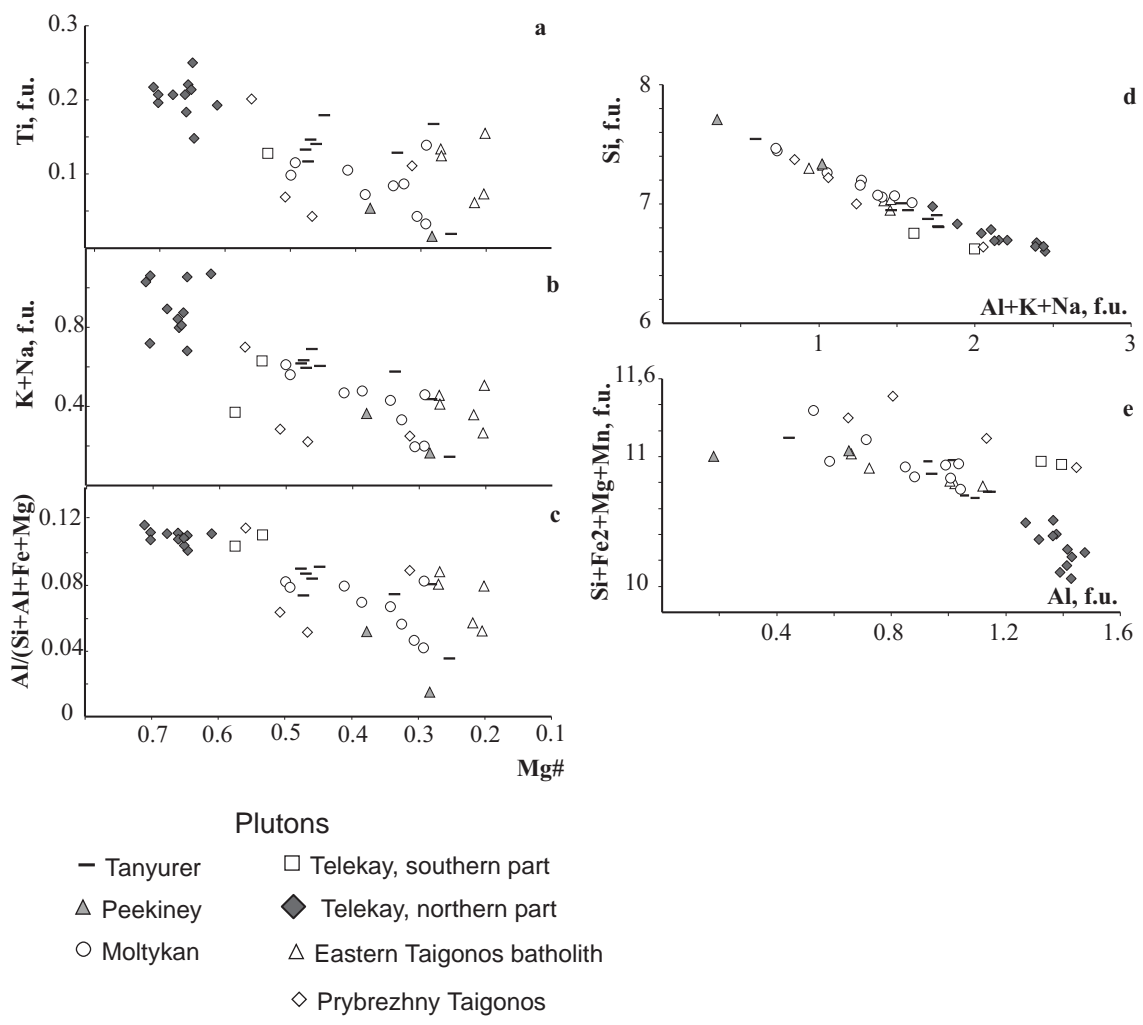

Fig. 8. Diagrams showing compositions of amphiboles from plutons studied. Symbols as in Fig. 3 (f.u.=formula unit).

(Eastern Taigonos and Tanyurer plutons) plot below the general trend (Fig. 11c, d). The dependency of the alumina content of biotite on the alkalinity of the granitoids (Marakushev and Tararin, 1965; Ivanov, 1970) is unclear.

\section{Estimating physicochemical conditions of melt crystallization}

We are compelled to admit that, despite the large number of techniques at hand, applying mineral geothermobarometry to real-life granite systems yields in many cases merely semiquantitative results. The reasons for these drawbacks are detailed in the summary of Anderson (1996).

The common mineral assemblages of granitoids have few phases that allow precise determination of the $P-T$ conditions of melt. The data at our disposal allow us to use the following geothermometers and geobarometers: (i) the zircon and apatite geothermometers of Watson and Harrison (1983) and Harrison and Watson (1984), (ii) the Ti amphibole geothermometer of Otten (1984), (iii) the modified amphibole geobarometer of Anderson and Smith (1995), (iv) the plagioclase-amphibole geothermometer of Holland and Blundy (1994), (v) the ilmenite-magnetite "thermooxometer" of Spencer and Lindsley (1981), and (vi) the biotite "thermooxometer" of Wones (1981). Two-feldspar ther- mometers (Fuhrman and Lindsley, 1988, etc.) are not very useful in application to the majority of natural granite systems, because of the high rate of subsolidus diffusion of the alkaline metals in K-Na-feldspars. We did not use the temperature estimates based on the proportions of normative quartz, albite, and K-feldspar (Tuttle and Bowen, 1958; Czamanske et al., 1981) because of their low accuracy.

The results of our calculations are summarized in Table 6 and on Figs. 12 and 13. The "zircon" and the "apatite" thermometers have yielded temperatures in the magmatic range, $700-980^{\circ}$. The "apatite" values in all cases are higher than the "zircon" ones, the difference occasionally exceeding $200^{\circ}$. This discrepancy may be due partly to the earlier appearance of apatite compared to zircon, and partly to the imperfection of the geothermometers as such. Because significant alumina oversaturation is not typical of the granitoids studied, it makes no sense to introduce the correction to the apatite thermometer as proposed by Bea et al. (1992). Temperature calculations from Ti abundances in amphiboles (Otten, 1984) give considerable scatter, yet to a first approximation they agree with the values obtained from the zircon saturation thermometer (Table 6). The existing discrepancies are quite easy to explain, because these two methods display the crystallization temperatures of different phases which might not have a paragenetic relation, even when they are components of the same rock. 


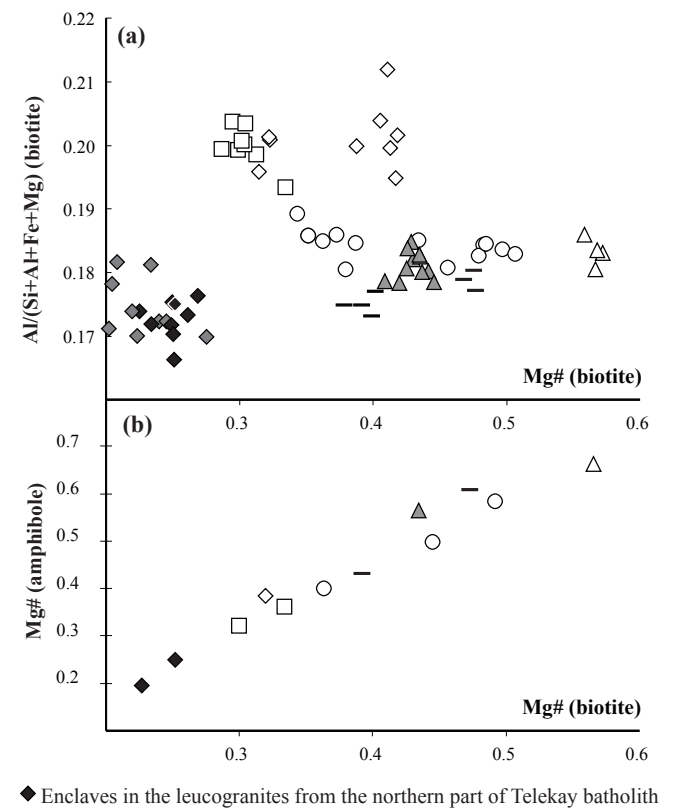

Fig. 9. Diagrams of (a) $\mathrm{Mg} \#$ vs. $\mathrm{Al} /(\mathrm{Si}+\mathrm{Al}+\mathrm{Fe}+\mathrm{Mg})$ for biotites and (b) biotite Mg\# vs. amphibole Fe\# for plutons studied. In (b), values averaged by the samples are used. Data for microgranular enclaves from northern Telekay leucogranites are included. Other symbols as in Fig. 3.

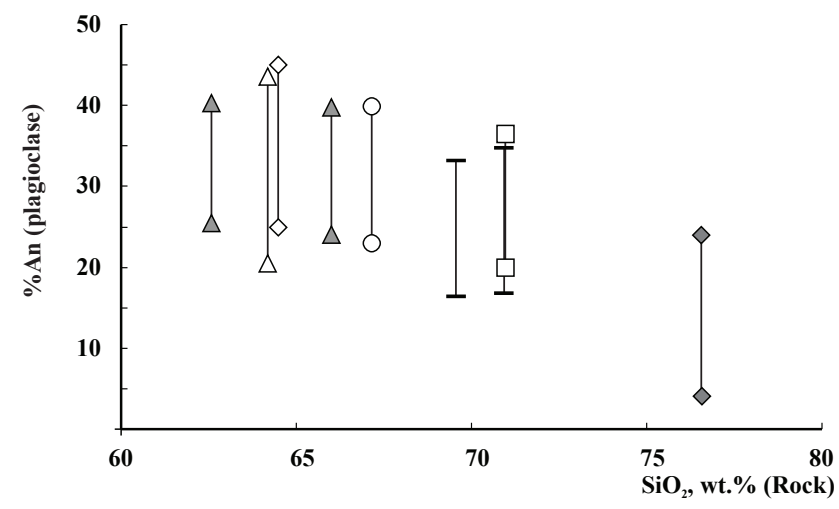

Fig. 10. Diagram $\mathrm{SiO}_{2}$ (rock) vs. An content (plagioclase, \%) for the plutons studied. Bars depict the full range of plagioclase composition in the studied samples. Symbols as in Fig. 3.

The considerable number of temperature estimates acquired by means of the modified version of the plagioclaseamphibole geothermometer of Holland and Blundy (1994) yield the subsolidus temperature, implying the postmagmatic transformation of the phases. The obviously subsolidus temperature values were discarded from further consideration. However, the temperature intervals acquired for some of the plutons are plausible, and overlap only slightly (Fig. 12a). For example, in the Tanyurer and Eastern Taigonos plutons, the plagioclase-amphibole equilibrium temperature ranges $650-770^{\circ} \mathrm{C}$, and in the Prybrezhny Taigonos belt, 750-

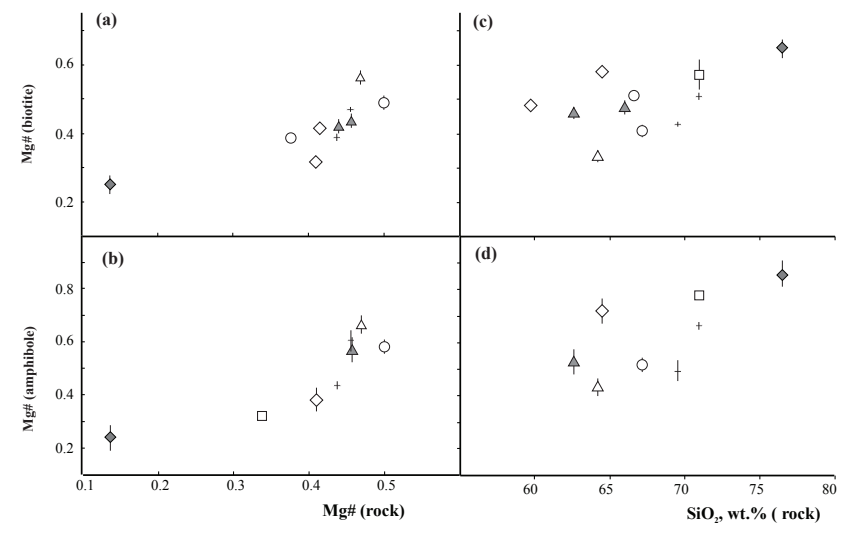

Fig. 11. Diagrams showing the relation between $\mathrm{Mg \#}$ of $\mathrm{Fe}-\mathrm{Mg}$ silicates and $\mathrm{Mg} \#(\mathbf{a}, \mathbf{b})$ and $\mathrm{SiO}_{2}$ content $(\mathbf{c}, \mathbf{d})$ of their host rocks. Bars depict the full measured range of mineral compositions (not shown if variations do not exceed the size of symbols in the diagram). Symbols as in Fig. 3.

$830^{\circ} \mathrm{C}$. These temperature estimates put constraints on the depth of magma emplacement (see Sect. 8.2)

The workability of the amphibole geobarometer based on the alumina content in amphiboles is limited by (1) the postmagmatic actinolitization, and (2) low Mg\# (0.2-0.4) of amphiboles in some granites. This geobarometer was calibrated for systems with relatively high oxygen potential and the amphibole Mg\# of 0.5-0.6. Anderson and Smith (1995) have shown that calculated pressure from the composition of highFe amphiboles leads to 2-3-fold overestimates. Accordingly, only the pressures obtained for the Eastern Taigonos and Tanyurer batholiths $(2.2 \mathrm{kbar}$ and $1.5-1.9 \mathrm{kbar}$, respectively) may be considered relatively reliable. As regards both parts of the Telekay pluton and intrusions of the Prybrezhny Taigonos belt, it can only be assumed that they crystallized at pressures no higher than $1-2 \mathrm{kbar}$.

The lack of hypersolvus assemblages in the low-Ca leucogranite of the northern part of the Telekay batholith suggests that the melt crystallized at water pressure of at least $0.5 \mathrm{kbar}$. Therefore, this intrusion was emplaced in a rather narrow depth interval $(1.5-3 \mathrm{~km})$. This is further supported by geological data (the intrusive contact of granites with the Late Jurassic-Early Cretaceous molassic unit, with a thickness of $3 \mathrm{~km}$ or less). The final estimate of the $P-T$ parameters of crystallization was made with due account for the position of solidus curves for water-saturated granitic magmas of various compositions (Johannes, 1996) (Fig. 12). We used this assumption despite the fact the fluid pressure is usually lower than the lithostatic pressure, because at the final stages of crystallization granitic melts are considered to be watersaturated (Johannes and Holtz, 1996). Exceptions come from "dry" hypersolvus granites, which are definitely not the case in point.

The low Ti contents in Ti-magnetites (Table 5) indicate significant subsolvus decay is quite common in granitoids 

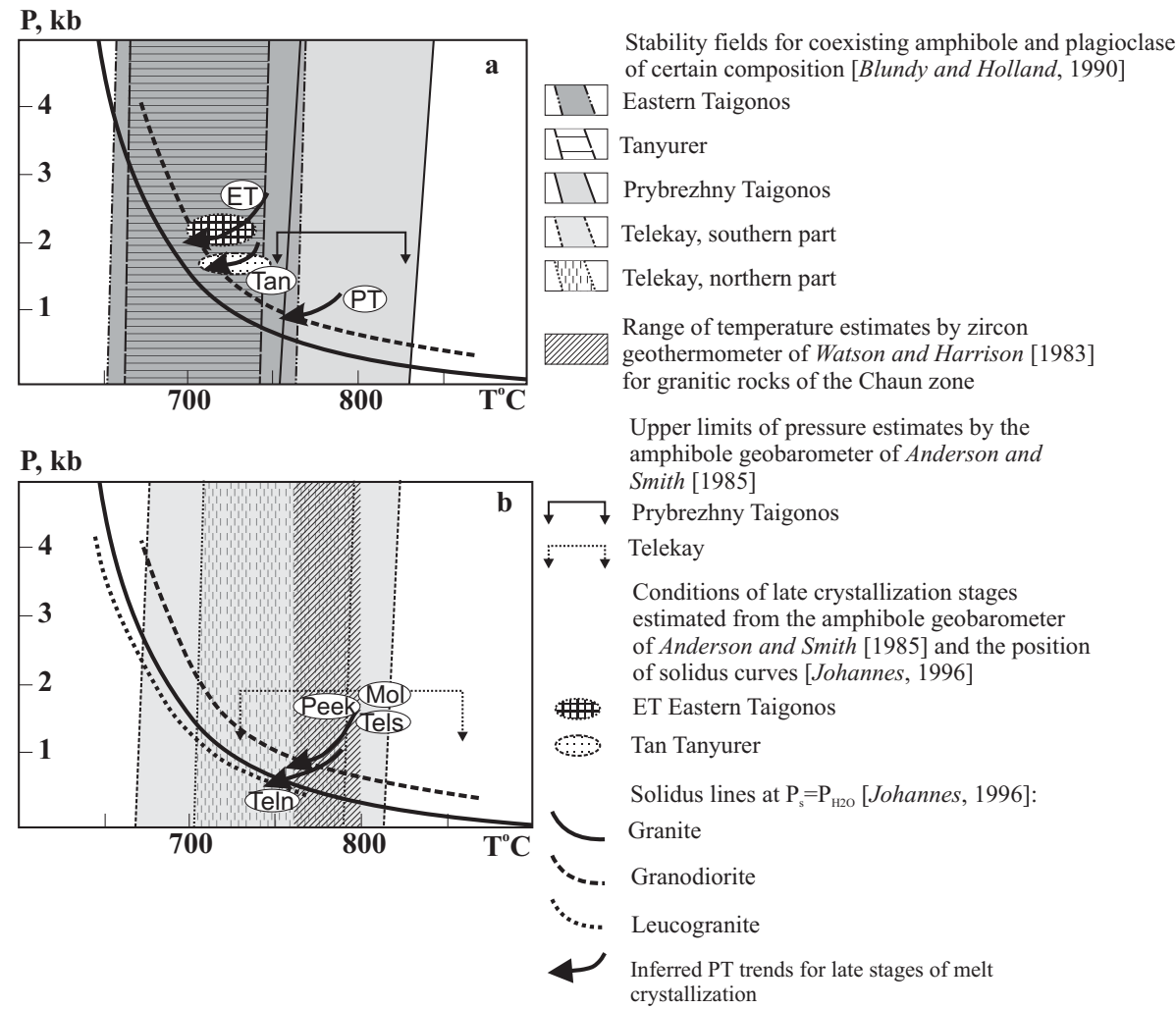

Fig. 12. Estimates of $P T$ crystallization conditions of the studied Cretaceous granitic plutons of NE Asia. Arrows depict the inferred PT-paths of late crystallization stages for plutons: ET - Eastern Taigonos, PT - Pribrezhny Taigonos, Tan Tanyurer, Peek - Peekiney, Tels - Telekay (southern part), Teln - Telekay (northern part), and Mol - Moltykan.

(Anderson, 1996). Ilmenites, on the contrary, are relatively resistant to solid-state transformations, and sometimes preserve the magmatic zoning. Because magnetite is present (at least in small amounts) in all rocks studied, we assumed that the ilmenite composition corresponds to equilibrium conditions and is suitable for estimating temperature and oxygen fugacity (Spencer and Lindsley, 1981). This approach does not yield any invariant values of $T$ and $\mathrm{fo}_{2}$, but allows the determination of magma crystallization conditions relative to the buffer equilibria curves (Table 6, Fig. 13). For the Tanyurer batholith, the observed hematite content in ilmenites is relatively low (4-5\%), and does not correspond with the presence of abundant magnetite. This inconsistency may be due to either subsolidus transformations or high manganese contents (14-15\% of pyrophanite - see Table 5), which impedes the incorporation of the hematitic component into ilmenite.

The equation proposed by Wones (1981) defines the link between the temperature and oxygen fugacity at which biotite of a certain composition coexists with K-feldspar and magnetite. Using the calculated curves (Fig. 13) and the previously acquired solidus temperatures (Fig. 12), we determined the $\mathrm{fo}_{2}$ values corresponding to the final stage of magmatic history of our granitoids. We assumed that the composition of biotite which lacks any magmatic zoning is indicative of near-solidus conditions (Anderson, 1996). The composition of the ilmenite, which preserves the traces of a magmatic zoning, was taken to estimate conditions of earlier crystallization stages. Thus, rough inferences about changes of redox conditions with the decreasing magma temperature are available (Fig. 13).

\section{Discussion}

\subsection{Rock chemistry and the origin of magmas}

Petrographically and chemically, all plutons considered in this article correspond to the I-type, usual for active continental margins and post-collisional uplifts (Pitcher, 1987). The plutons do not reveal any significant depletion in HREE (Fig. 5c, d). Therefore, the contribution of garnet-bearing granulites to magma generation appears to be negligible, thus suggesting that the magma source was within the upper or middle continental crust. Also, all plutons exhibit some evidence of contributions from mantle sources. For Tanyurer and Taigonos plutons, there are intrusive bodies of gabbro and diorites, and for the Chaun zone plutons, there are microgranular enclaves produced by the injection of mafic magmas into the partially crystallized felsic matrix (Vernon, 1991). 


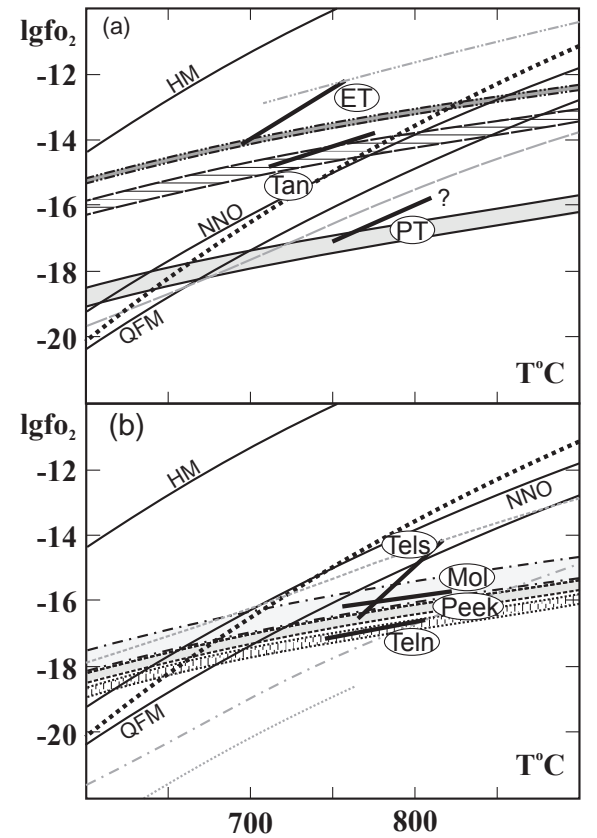

Regions incorporating the upper boundaries of the biotite stability fields [Wones, 1981]

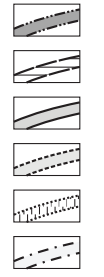

Eastern Taigonos

Tanyurer

Prybrezhny Taigonos

Telekay, southern part

Telekay, northern part

Moltykan and Peekiney

Ilmenite stability curves

Eastern Taigonos

Tanyurer

Telekay, southern part

Telekay, northern part

Moltykan and Peekiney

Inferred $\mathrm{fo}_{2}-\mathrm{T}$ trends of the late stages of melt crystallization, determined with account for the estimated solidus temperatures (Fig. 12)

Buffer equilibria curves

Lines of equilibrium $\mathrm{hd}+\mathrm{il}=\mathrm{sph}+\mathrm{mt}+\mathrm{q}$, approximately defining the boundary of the regions of the magnetite- and ilmenite series of granites [Wones, 1989]

Fig. 13. Estimates of $\mathrm{fo}_{2}-T$ conditions of crystallization of the studied Cretaceous granitic plutons of NE Asia.

Table 6. Estimates on crystallization conditions of granitic plutons studied.

\begin{tabular}{|c|c|c|c|c|c|c|}
\hline \multirow{3}{*}{$\begin{array}{l}\text { Parameters } \\
\text { Primary } \\
\text { data }\end{array}$} & \multicolumn{4}{|c|}{ Temperature, ${ }^{\circ} \mathrm{C}$} & \multirow{2}{*}{$\begin{array}{l}\text { Oxygen fugacity* } \\
\text { neral composition }\end{array}$} & \multirow[t]{3}{*}{ Pressure, kbar** } \\
\hline & \multicolumn{2}{|c|}{ Rock composition } & \multicolumn{2}{|c|}{ Mineral composition } & & \\
\hline & $\begin{array}{l}\mathrm{Zr} \text { content } \\
\text { (zircon saturation) }\end{array}$ & $\begin{array}{l}\mathrm{P} \text { content } \\
\text { (apatite saturation) }\end{array}$ & amphibole & $\begin{array}{l}\text { amphibole+ } \\
\text { plagioclase }^{* * *}\end{array}$ & $\begin{array}{l}\text { ilmenite, } \\
\text { biotite }\end{array}$ & \\
\hline Reference & $\begin{array}{l}\text { Watson and } \\
\text { Harrison (1983) }\end{array}$ & $\begin{array}{l}\text { Harrison and } \\
\text { Watson (1984) }\end{array}$ & Otten (1984) & $\begin{array}{l}\text { Holland and } \\
\text { Blundy (1994), } \\
\text { edenite-richterite } \\
\text { equilibrium }\end{array}$ & $\begin{array}{l}\text { Spencer Lindsley (1981), } \\
\text { Wones (1981) }\end{array}$ & $\begin{array}{l}\text { Anderson and } \\
\text { Smith (1995) }\end{array}$ \\
\hline $\begin{array}{l}\text { Plutons } \\
\text { Eastern }\end{array}$ & & & & & & \\
\hline $\begin{array}{l}\text { Taigonos } \\
\text { Prybrezhny }\end{array}$ & $724 \pm 26(n=10)$ & $837 \pm 97(\mathrm{n}=11)$ & $675 \pm 62(\mathrm{n}=5)$ & $650-770$ & $\mathrm{NNO}+2$ & $2.2 \pm 0.5(\mathrm{n}=1)$ \\
\hline Taigonos & $730 \pm 44(n=5)$ & $865 \pm 126(n=11)$ & $670 \pm 97(n=4)$ & $755-830$ & QFM & $2.2 \pm 0.6^{* * * *}(\mathrm{n}=1)$ \\
\hline Tanyurer & $754 \pm 31(\mathrm{n}=2)$ & $932 \pm 63(n=46)$ & $717 \pm 44(\mathrm{n}=7)$ & $665-745$ & $\mathrm{NNO}+0.5$ & $1.7 \pm 0.9(\mathrm{n}=5)$ \\
\hline Peekiney & $785 \pm 27(n=4)$ & $951 \pm 44(n=6)$ & - & - & from QFM-2 to QFM & - \\
\hline $\begin{array}{l}\text { Moltykan } \\
\text { Telekay }\end{array}$ & $787 \pm 22(\mathrm{n}=2)$ & $980 \pm 49(n=94)$ & - & - & from QFM-2 to QFM & - \\
\hline $\begin{array}{l}\text { (northern part) } \\
\text { Telekay }\end{array}$ & $763 \pm 12(\mathrm{n}=1)$ & $944 \pm 101(n=4)$ & $788 \pm 55(n=11)$ & $705-790$ & from QFM-2 to QFM-1 & $1.8 \pm 1.0^{* * * *}(\mathrm{n}=12)$ \\
\hline (southern part) & $780 \pm 29(n=2)$ & $953 \pm 44(\mathrm{n}=9)$ & $621 \pm 123(\mathrm{n}=2)$ & $670-815$ & QFM & $1.9 \pm 0.8^{* * * *}(\mathrm{n}=2)$ \\
\hline
\end{tabular}

* in log units relative to buffer equilibria; ${ }^{* *}$ determinations on amphiboles, which do not contain considerable amounts of the tremoliteactinolite component; ${ }^{* * *}$ full interval of temperature estimations in suggested interval of pressure (see Fig. 12); **** values, considered as overestimated due to low Mg\# of amphiboles (Anderson and Smith, 1995). Number of determinations is given in parentheses. 
The involvement of subduction-related magmatic complexes into the petrogenesis is evident from $\mathrm{Nb}$-Ta minimum and enrichment in LILE (Fig. 5a, b). For the Tanyurer and Eastern Taigonos batholiths, the relation with an active margin is evident from the geologic and geochronologic data. Granites of the Prybrezhny Taigonos belt have the lowest K/Na and ASI values, the and the least fractionated REE among all plutons studied (Figs. 4a, c, and 6b). Besides, they are closely associated with gabbro and diorites. All these facts suggest that, at least partially, the granitic magmas were formed through the fractionation of mafic melts, rather than through the partial melting of crustal protolith. This hypothesis is concordant with geologic data that imply the origin of host complexes of the Prybrezhny Taigonos belt in an island arc setting (Sokolov et al., this volume). Tanyurer and Eastern Taigonos batholiths also comprise some gabbros and diorites but in much lesser amounts, and the process of mafic melts fractionation could not have played a major role in their formation.

Granitic rocks of the Chaun tectonic zone are compositionally distinct from subduction-related Taigonos and Tanyurer granites, despite having the same $\mathrm{Ta}-\mathrm{Nb}$ minimum and LILE enrichment. They are relatively homogenous, and enriched in all incompatible lithophile elements, especially LILE (Figs. 5 and 6). This enrichment could be controlled by the composition of the crustal protolith, with a greater portion of metapelites and lesser portion of juvenile mantle-derived rocks relative to the source of Taigonos granites. However, incompatible element abundances and $\mathrm{K} / \mathrm{Na}$ ratio do not depend on $\mathrm{SiO}_{2}$ contents in Chaun granites (Fig. 4b). Therefore, the granodioritic and granitic magmas could also inherit their compositional peculiarities from mafic mantle-derived melts. This hypothesis is supported by the presence of highly enriched Early Cretaceous shoshonitic volcanic rocks within the Chaun zone (Tikhomirov et al., 2006b). As both Chaun granites and those shoshonites are relatively depleted in Ta and $\mathrm{Nb}$, any contribution from plume sources is unlikely. The origin of their "subductional" geochemical specifics may be explained by the generation of their mantle-derived components within the mantle wedge of a former subduction zone.

The Telekay batholith is a particular case. Its northern part is composed of leucogranites crystallized from a nearcotectic magma. Such a considerable volume of high-silica melt could be produced only by the melting of a felsic continental crust, which likely comprised some ancient granitic bodies. In this case, geochemical traces of the initial protolith composition are weak or absent. The southern part of the Telekay pluton reveals the compositional characteristics transitional between those of other granites of the Chaun zone, and the subduction-related rocks of Tanyurer and Taigonos plutons (Figs. 4a, b, 6, and 7). As there are no reasons to believe the southern part of the Telekay batolith was formed in a tectonic environment distinct from that of other granites of the Chaun zone, we conclude that the geodynamic setting itself has a minor influence on a composition of granites studied. A more effective factor is the composition of the crustal protolith which may exhibit significant variations. Probably for this reason, granodiorites of the post-orogenic southern Telekay pluton cannot be distinguished from granodiorites of the subduction-related Tanyurer batholith solely on the basis of rock chemistry (Figs. 4 and 5b). These two plutons are located not far from each other (Fig. 2), and may include derivatives from the same crustal source.

\subsection{Crystallization conditions}

None of mineral geothermometers and geobarometers available yield results applicable to all plutons studied. The most plausible data were obtained using the zircon saturation thermometer (Watson and Harrison, 1983) and the corrected amphibole geobarometer (Anderson and Smith, 1995). The combination of these data with the $P-T$ parameters of water-saturated melting of granites (Johannes, 1996) allows us to estimate the emplacement depth of the plutons. These estimates systematically decrease from the Eastern Taigonos batholith $(6-7 \mathrm{~km})$ to the Tanyurer pluton $(4-5 \mathrm{~km})$ to the Prybrezhny Taigonos pluton (2-4 km?) through to the Chaun zone plutons (1.5-3 km) (Fig. 12). For the Telekay and Peekiney plutons, these estimates correspond well with geologic data (granites intrude molassic units with a thickness of 1 to $3 \mathrm{~km}$ ). Regarding the Moltykan batholith and other plutons of the Chaun zone, the depth constraints are less clear. Nonetheless, most plutons located up to $300 \mathrm{~km}$ east from the Chaunskaya Bay are texturally and compositionally similar, and their emplacement was controlled by faults of the same NE strike, so they could have been emplaced at similar depths.

Thus, post-orogenic plutons of the Chaun zone appear to be formed at lesser depth than subduction-related Tanyurer and Taigonos plutons. However, the effect of different erosional incision may be important as well. For instance, the Eastern Taigonos batholith is located within the deeply eroded tectonic block, where amphibolite-facies metamorphic rocks crop out, and no volcanic sequences coeval with granites have been preserved. But the Tanyurer batholith reveals the depth of erosional incision similar to (if not less than) that of Chaun zone plutons. Therefore, the variations of the emplacement depth could be caused by the systematic differences in magma dynamics. Shallow emplacement depth is frequently considered as a feature of relatively dry and high-temperature granitoid magmas (Hyndman, 1981). This might serve as an additional indirect evidence of mantle magma contribution to the petrogenesis of the Chaun zone plutons, despite their relatively homogenous composition (Figs. 3 and 4).

The redox conditions of crystallization of the rocks studied are broadly variable, which is readily apparent from observations under an ore microscope: the plutons considered include both magnetite-series granites (Eastern Taigonos and Tanyurer) and ilmenite-series ones (all the 
rest). Magnetite-series granitoids are distinguished by the relatively high $\mathrm{Mg \#}$ of mafic minerals (Figs. 8, 9, and 11), a long known fact (Czamanske et al., 1981; Wones, 1981) explained by the extraction of Fe from silicates into oxides with increasing oxygen potential.

The study performed has not revealed any significant role of geodynamic regime in the control over oxidation potential of granitoid melts. Hence, there are no grounds to believe that the rocks of the Eastern Taigonos pluton and Prybrezhny Taigonos belt were generated in markedly different settings, although their estimated oxygen fugacity values differ by roughly two orders of magnitude (Fig. 13a). Thus it is reasonable to assume that this parameter, just like geochemical signatures of the rocks, is primarily defined by local peculiarities of magma source composition, e.g., the presence of metasediments with elevated organic carbon abundance. Our knowledge of the composition of the crystalline basement under the Chukotka area is still poor, but the Triassic sediments comprise a lot of black shales with a high organic content. Either direct contribution of these rocks to magma generation, or the presence of similar complexes in the PreMesozoic basement could seriously affect the redox state of crustal magmas.

\section{Conclusions}

1. Magmas which produced the studied granitoid plutons were derived from a compositionally heterogeneous protolith in the upper or middle continental crust, with direct contributions from mantle sources. Towards the inner parts of continental blocks, the portion of mafic magmas involved in the petrogenesis decreases, while the abundances of incompatible lithophile elements in granitic magmas increase.

2. Both post-orogenic plutons of the Chaun tectonic zone and the subduction-related plutons (Tanyurer batholith and Taigonos granitic belts) display geochemical affinity with calc-alkaline series of active continental margins, and inherit the compositional peculiarities of their mantle sources. However, within each geodynamic group of granites, there are compositional variations, which may disguise systematic differences between the two groups. These variations are likely caused by the heterogeneity of crustal protolith.

3. The trace element composition of Chaun zone granites rules out any significant contribution from plume sources. Thus, their origin may be related with tectonic processes at the extinct active margin of former AnyuiAngayucham oceanic basin (slab delamination), and/or at the active margin of ancestral Pacific (back-arc extension or strike-slip stress).

4. Final crystallization of the studied plutons occurred at comparatively shallow depths, between 1-2 and
6-7 km, in a temperature interval of $700-770^{\circ} \mathrm{C}$. Postorogenic granites were emplaced at lesser depth than subduction-related plutons, likely due to lesser water contents in magmas.

5. Variations in for values at the late stages of crystallization of the granites range over 3-4 orders of magnitude, exceeding the limits of the quartz-fayalite-magnetite (QFM) and nickel-nickel oxide (NNO) buffer equilibrium, which is due likely to the local peculiarities of the source composition.

Acknowledgements. This work was supported by the Russian Foundation for Basic Research (grant nos. 03-05-64623, 07-05-00255) and by the Universities of Russia and the Leading Scientific Schools programs (grant no. NSh-326.2003.5, NSh-9664.2006.5, NSh-3172.2008.5). Authors are thankful to J. Toro for helpful and constructive review.

\section{References}

Anonymous: Accelerated chemical methods of determination of rock-forming elements in rocks and ores, Federal ScientificMethodical center of Laboratory Studies and Certification of Mineral Resources "VIMS", Moscow, 53 pp., (in Russian) 2005.

Anderson, J. L.: Status of thermobarometry in granitic batholiths, Transactions of the Royal Society of Edinburgh, Earth Sciences, 87, 125-138, 1996.

Anderson, J. L. and Smith, D. R.: The effects of temperature and $\mathrm{f}\left(\mathrm{O}_{2}\right)$ on the Al-in-hornblende barometer, Am. Mineral., 80, 549-559, 1995.

Barbarin, B.: Granitoids: main petrogenetic classifications in relation to origin and tectonic setting, Geol. J., 25, 227-238, 1990.

Bea, F., Fershtater, G., and Corretgé, L. G.: The geochemistry of phosphorus in granite rocks and the effect of aluminium, Lithos, 29, 43-56, 1992.

Belyi, V. F.: Stratigraphy and structures of the Okhotsk-Chukotka volcanic belt, Nauka, Moscow, 171 pp., 1977 (in Russian).

Bondarenko, G. E., Morozov, O. L., Layer, P., and Minyuk, P. S.: New Ar-Ar isotope dates from magmatic and metamorphic rocks from the Taigonos Peninsula (NE Russia), Dokl. Akad. Nauk+, 369, 76-83, 1999.

Chekhov, A. D. and Palandzhyan, S. A.: Exotic terranes of Taigonos Peninsula, Northeastern Russia, paper presented at Intern. Confer. on Arctic Margin, Magadan, Russia, 6-10 September 1995.

Chubarov, V. I. and Vyatkin, B. V.: An explanatory notes to the State geologic map of the USSR, scale 1:200000, area Q-60-VII,VIII (lake Baranye), Q-60-IX, X (lakes Dlinnye), Anadyrskaya GRE, Anadyr., 1988 (in Russian).

Czamanske, G. K., Ishihara, S., and Atkin, S. A.: Chemistry of rock-forming minerals of the Cretaceous-Paleocene batholith in southwestern Japan and implications for magma genesis, J. Geophys. Res., 86, 10431-10 469, 1981.

Efremov, S. V., Dudkinsky, D. V., and Kozlov, V. D.: Granitoids of the eastern coast of the Chaun Estuary, paper presented at 4th Regional Petrographic Conference on the Northeast of Russia, Magadan, Russia, 141-145 (in Russian), 2000.

Fuhrman, M. L. and Lindsley, D. H.: Ternary feldspar modelling and thermometry, Am. Mineral., 73, 727-740, 1988. 
Harmon, R. S., Halliday, A. N., Clayburn, J. A. P., and Stephens, W. E.: Chemical and isotopic systematics of the Caledonian intrusions of Scotland and northern England: a guide to magma source region and magma-crust interaction, Philos. T. R. Soc. A, 310, 709-742, 1984.

Harrison, T. M. and Watson, E. B.: The behavior of apatite during crustal anatexis: Equilibrium and kinetic considerations, Geochim. Cosmochim. Ac., 48, 1467-1477, 1984.

Holland, T. and Blundy, J.: Non-ideal interactions in calcic amphiboles and their bearing on amphibole-plagioclase thermometry, Contrib. Mineral. Petr., 116, 433-447, 1994.

Hourigan, J.: Mesozoic-Cenozoic tectonic and magmatic evolution of the northeast Russian margin, Ph.D. thesis, Stanford University, Stanford, California, 257 pp., 2003.

Hyndman, D. W.: Controls on source and depth of emplacement of granitic magma, Geology, 9, 244-249, 1981.

Ivanov, V. S.: On the influence of temperature and chemical activity of potassium on biotite composition in granitoids (a case study in the Western and Eastern Iultinsky intrusions, central Chukotka), Izv. AN SSSR Geol+, 7, 20-30, 1970 (in Russian).

Ispolatov, V. O., Tikhomirov, P. L., Heizler, M., and Cherepanova, I. Yu.: New ${ }^{40} \mathrm{Ar} /{ }^{39} \mathrm{Ar}$ ages of Cretaceous continental volcanics from central Chukotka: implications for initiation and duration of volcanism within northern part of the Okhotsk-Chukotka Volcanic Belt (northeastern Eurasia), J. Geol., 112, 369-377, 2004.

Johannes, W.: The significance of experimental studies for the formation of migmatites, in: Migmatites, edited by: Ashworth, J. R., Blackie, Glasgow, 36-85, 1996.

Johannes, W. and Holtz, F.: Petrogenesis and Experimental Petrology of Granitic Rocks, Springer-Verlag, 333 pp., 1996.

Katkov, S. M., Strickland, A., Miller, E. L., and Toro, J.: Ages of granite batholiths from Anyui-Chukotka fold belt, Dokl. Earth Sci., 414, 515-518, 2007.

Le Maitre, R. W. (Ed.): A classification of igneous rocks and glossary of terms, Blackwell Scientific, Oxford, 193 pp., 1989.

Luchitskaya, M. V.: Geochemical characteristic of granitoids of the Eastern Taigonos and Prybrezhny Taigonos belts, southern Taigonos Peninsula: Similarity to and dissimilarity from the I- and M-type granites, Byull. Mosk. O-va Ispyt. Prirody. Otd. Geol., 76, 52-62, 2001.

Luchitskaya, M. V., Hourigan, G., Bondarenko, G. E., and Morozov, O. L.: New data of SHRIMP U-Pb study on zircons from granitoids of the Prybrezhny- and Eastern Taigonos belts, southern part of the Taigonos Peninsula, Dokl. Akad. Nauk+, 389, 763-769, 2003.

Marakushev, A. A. and Tararin, I. A.: On the mineralogical criteria of alkalinity of granitoids, Izv. AN SSSR Geol.+, 20-38, 1965.

Markov, M. S.: Metamorphic complexes and "basaltic" layer of earth crust of island arcs, Nauka, Moscow, 232 pp., 1975 (in Russian).

Miller, E. L., Toro, J., Gehrels, G., Tuchkova, M. I., and Katkov, S. M.: Detrital Zircon Ages from Late Jurassic-Early Cretaceous Myrgovaam Basin Sandstones (Rauchua Trough), Western Chukotka, NE Russia, Eos T. Am. Geophys. Un., 85(47), Fall Meeting Supplement, Abstract GP44A-04, 2004.

Miller, E. L. and Verzhbitsky, V.: Structural studies near Pevek, Russia: Implications for formation of the East Siberian Shelf and Makarov Basin of the Arctic Ocean, in: Origin of Northeast Russia: Paleomagnetism, Geology \& Tectonics, edited by: Stone, D.
B., University of Alaska Geophysical Institute Report UAG-R330, 2006.

Morozov, O. L.:, Geological structure and tectonic evolution of Central Chukotka, Transactions of GIN RAS, Vol. 523, GEOS, Moscow, 201 pp., 2001 (in Russian).

Natal'in, B. A.: The Early Mesozoic eugeosynclinal systems in the northern part of the Circum-Pacific belt, Nauka, Moscow, 136 pp., 1984 (in Russian).

Nekrasov, G. E.: Tectonics and magmatism of the Taigonos Peninsula and northwestern Kamchatka, Nauka, Moscow, 176 pp., 1976 (in Russian).

Nokleberg, W. J., Parfenov, L. M., Monger, J. W. H., Norton, I. O., Khanchuk, A. I., Stone, D. B., Scotese, C. R., Scholl, D. W., and Fujita, K.: Phanerozoic tectonic evolution of the Circum-North Pacific, US Geological Survey (USGS) Professional Paper 1626, 2001.

Otten, M. T.: The origin of brown hornblende in the Artfjället gabbro and dolerites, Contrib. Mineral. Petr., 86, 189-199, 1984.

Parfenov, L. M., Natapov, L. M., Sokolov, S. D., and Tsukanov, N. V.: Exotic terranes and accretionary tectonics of the northeast of Asia, Geotectonics, 68-78, 1993.

Pearce, J. A., Harris, N. B. W., and Tindle, A. G.: Trace element discrimination diagrams for the tectonic interpretation of granitic rocks, J. Petrol., 25, 956-983, 1984.

Pitcher, W. S.: Granites and yet more granites forty years on, Geol. Rundsch., 76, 51-79,1987.

Pysharovsky, Yu. M. and Tilman, S. M. (Eds.): Essays of Koryak Highland tectonics, Nauka, Moscow, 220 pp., 1982 (in Russian).

Pysharovsky, Yu. M., Sokolov, S. D., Til'man, S. M., and Krylov, K. A.: Tectonics and geodynamics of the northwestern framework of Pacific Ocean, Problems of Tectonics, Mineral and Energetic resources of North-West Pacific, Khabarovsk, 1, 128-137, 1992 (in Russian).

Read, H. H.: The Granite Controversy, Thomas Murby and Co., London, 430 pp., 1957.

Rokhlin, M. I.: Some features of the Pevek Peninsula metallogeny, Problems of Arctics, 5, 3-22, 1938 (in Russian).

Sokolov, S. D.: Accretionary tectonics of the Koryak-Chukotka segment of the Pacific belt, Nauka, Moscow, 1992 (in Russian).

Sokolov, S. D., Bondarenko, G. E., Morozov, O. L., and Luchitskaya, M. V.: The tectonics of the junction zone between the Verkhoyansk-Chukotka and Koryak-Kamchatka fold areas, Byull. Mosk. O-va Ispyt. Prirody. Otd. Geol., 76, 24-37, 2001.

Sokolov, S. D., Bondarenko, G. Ye., Morozov, O. L., Shekhvostov, V. A., Glotov, S. P., Ganelin, A. V., and Kravchenko-Berezhnoi, I. R.: South Anyui suture, northeast Arctic Russia: Facts and problems, Geological Society of America, Special Paper, 360, 209-224, 2002.

Sokolov, S. D.: Accretionary tectonics: the state of the art, Geotectonics, 37, 1-14, 2003.

Spencer, K. J. and Lindsley, D. H.: A solution model for coexisting iron-titanium oxides, Am. Mineral., 66, 1189-1201, 1981.

Stavsky, A. P., Chekhovich, V. D., Kononov, M. V., and Zonenshain, L. P.: Plate tectonics and palinspastic reconstructions of AnadyrKoryak region, Geotectonics, 6, 32-42, 1988 (in Russian).

Sun, S.-S. and McDonough, W. F.: Chemical and isotopic systematics of oceanic basalts: implications for mantle composition and processes, Spec. Publ. Geol. Soc. London, 42, 313-345, 1989.

Taylor, S. R. and McLennan, S. M.: The Continental Crust: 
its Composition and Evolution, Blackwell Scientific, Oxford, 312 pp., 1985.

Tikhomirov, P. L.: Petrology of granitoids of the Telekay ore district (central Chukotka), Ph.D. thesis, St. Petersburg, 1998 (in Russian).

Tikhomirov, P. L., Akinin, V. V., Ispolatov, V. O., Alexander, P., Cherepanova, I. Yu., and Zagoskin, V. V.: The OkhotskChukotka Volcanic Belt: Age of Its Northern Part According to New Ar-Ar and U-Pb Geochronological Data, Stratigr. Geol. Correl., 14, 524-537, 2006a.

Tikhomirov, P. L., Akinin, V. V., Kalinina E. A., and Nakamura, E.: Cretaceous volcanism of the North Chukotka area (NE Russia): new geochronological and geochemical constraints. The Evolution of Early Stage of Earth and Solar System, 2nd Misasa International Symposium, Kurayoshi, Japan, 68-69, 2006b

Tilman, S. M.: Tectonics of continental margins of Pacific Ocean north-east. Nauka, Moscow, 285 pp., 1980 (in Russian).

Tuttle, O. F. and Bowen, N. L.: Origin of granite in the light of experimental studies in the system $\mathrm{NaAlSi}_{3} \mathrm{O}_{8}-\mathrm{KAlSi}_{3} \mathrm{O}_{8}-\mathrm{SiO}_{2}-$ $\mathrm{H}_{2} \mathrm{O}$, Geol. Soc. Am. Mem., 74, 153 pp., 1958.

Ueda, H. and Miyashita, S.: Tectonic accretion of a subducted intraoceanic remnant arc in Cretaceous Hokkaido, Japan, and implications for evolution of the Pacific northwest, Island Arc, 14, 582-598, 2005
Vernon, R. H.: Microgranitoid enclaves in granites - globules of hybrid magma quenched in a plutonic environment, Nature, 309, 438-439, 1991.

Watson, E. B. and Harrison, T. M.: Zircon saturation revisited: Temperature and composition effects in a variety of crustal magma types, Earth Planet. Sci. Lett., 64, 295-304, 1983.

Wones, D. R.: Mafic silicates as indicators of intensive parameters in granitic magmas, Min. Geol., 31, 191-212, 1981.

Zaborovskaya, N. B..: Vnutrennyaya zone of Okhotsk-Chukotka volcanic belt on Taigonos, Nauka, Moscow, 199 pp., 1978 (in Russian).

Zagruzina, I. A.: The geochronology of the Mesozoic granitiods of the Northeastern USSR, Nauka, Moscow, 277 pp., 1977 (in Russian)

Zhulanova, I. L.: Earth's crust of the North-East Asia in Precambrian and Phanerozoic, Nauka, Moscow, 302 pp., 1990 (in Russian).

Zolotarev, B. P. and Margolin, E. M.: Geochemistry and rare-earth element abundances of basalts from sites 482, 483, and 485 in the Gulf of California, Initial Reports of the Deep Sea Drilling Project, LXV, Washington, 579-590, 1983.

Zonenshain, L. P., Kuz'min, M. I., and Natapov L. M.: Tectonics of lithospheric plates of the USSR territory, Nauka, Moscow, Book 2, 334 pp., 1990 (in Russian). 